\title{
Data report: raw and normalized elemental data along the Site U1335, U1336, and U1337 splices from X-ray fluorescence scanning ${ }^{1}$
}

\author{
Julia K. Shackford, ${ }^{2}$ Mitchell Lyle, ${ }^{2}$ Roy Wilkens, ${ }^{3}$ and Jun Tian ${ }^{4}$
}

\begin{abstract}
Chapter contents

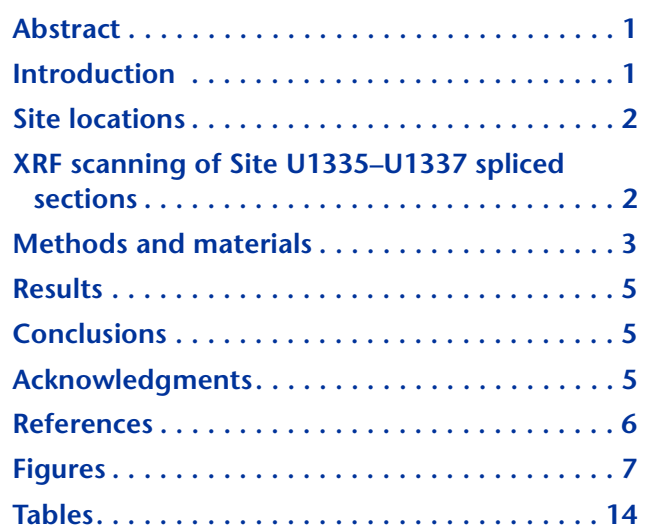

'Shackford, J.K., Lyle, M., Wilkens, R., and Tian, J., 2014. Data report: raw and normalized elemental data along the Site U1335, U1336, and U1337 splices from X-ray fluorescence scanning. In Pälike, H., Lyle, M., Nishi, H., Raffi, I., Gamage, K., Klaus, A., and the Expedition 320/321 Scientists, Proc. IODP, 320/321: Tokyo (Integrated Ocean Drilling Program Management International, Inc.). doi:10.2204/iodp.proc.320321.216.2014 ${ }^{2}$ College of Geosciences, Texas A\&M University, MS3146, Oceanography and Meteorology Building, College Station TX 77843, USA. Correspondence author: jkshackford@ocean.tamu.edu ${ }^{3}$ Hawaii Institute of Geophysics and Planetology, University of Hawaii at Manoa, 1680 East West Road, Honolulu HI 96822, USA. ${ }^{4}$ Laboratory of Marine Geology, Tongji University, Siping Road 1239, Shanghai 200092, P.R.China.

\section{Abstract}

We used X-ray fluorescence (XRF) scanning on samples from Integrated Ocean Drilling Program Expeditions 320/321 Sites U1335U1337 to measure sediment geochemical compositions at 2.5 and $5 \mathrm{~cm}$ resolution for a total of $937 \mathrm{~m}$ of spliced sediment column. Site U1335 was scanned from 0 to 302 meters composite depth (mcd), Site U1336 was scanned from 0 to $142.5 \mathrm{mcd}$, and Site U1337 was scanned from 0 to $491.6 \mathrm{mcd}$, which is the entire splice. Here we report the data and describe the data acquisition conditions to measure $\mathrm{Al}, \mathrm{Si}, \mathrm{K}, \mathrm{Ca}, \mathrm{Ti}, \mathrm{Mn}, \mathrm{Fe}$, and $\mathrm{Ba}$ in the solid phase. We also describe a method to convert data from volumebased raw XRF scan data to a normalized mass measurement, ready for calibration by other geochemical methods. Both the raw and normalized data are reported along each of the splices for Sites U1335-U1337.

\section{Introduction}

One primary objective of the Integrated Ocean Drilling Program (IODP) Pacific Equatorial Age Transect (PEAT) project is to produce continuous records tracking the effects of climate change in the eastern equatorial Pacific with enough detail to resolve orbitally forced climate cycles. A significant part of climate change is recorded by variability in the chemical composition of sediment, but this information is typically difficult to extract at a reasonable cost (see the "Methods" chapter [Expedition 320/321 Scientists, 2010a]).

$\mathrm{X}$-ray fluorescence (XRF) scanning is an economical and nondestructive way to extract chemical data from split cores. XRF scanning is an X-ray optical technique that can measure the majority of the major elements and some minor elements in $\sim 20-30$ s per measurement. The vertical spacing at which data were collected for this project is similar to that at which physical properties were gathered on board the ship. The chemical measurements collected from XRF scanning can supplement physical properties measurements to study cyclostratigraphy. If calibrated, XRF scan data can be used to understand the long-term evolution of biogeochemical cycles.

In this data report, we present the results of XRF scanning on the spliced sedimentary sections from Sites U1335-U1337 and describe a basic technique, following Lyle et al. (2012), used to nor- 
malize the data for further geochemical study. Both the raw and normalized data along the splices are presented in Tables T1, T2, and T3. We report depth in meters composite depth (mcd) using core composite depth below seafloor (CCSF-A) methodology (see the "Methods" chapter [Expedition 320/321 Scientists, 2010a]). Data at this sampling resolution collected from multiple cores along the transect, along with previously published data from Site U1338 (Lyle et al., 2012; Lyle and Backman, 2013), allow the study of geochemical cycles for long periods of time and across great distances in the eastern equatorial Pacific. Such data can be used to study how biogeochemical changes in the equatorial Pacific are related to long-term changes in global climate.

\section{Site locations}

The three sites in this data report, along with Site U1338, contain the major Neogene sediment sections for the PEAT equatorial Pacific megasplice. The sites are located between $7^{\circ} 42^{\prime} \mathrm{N}$ and $3^{\circ} 50^{\prime} \mathrm{N}$ (Fig. F1).

\section{Site U1335}

Site U1335 $\left(5^{\circ} 18.735^{\prime} \mathrm{N}, 126^{\circ} 17.002^{\prime} \mathrm{W} ; 4327.5 \mathrm{~m}\right.$ water depth) is on $\sim 26$ Ma crust halfway between Site U1336, $\sim 340 \mathrm{~km}$ to the northwest, and Site U1337, $\sim 390 \mathrm{~km}$ to the southeast, and $\sim 250 \mathrm{~km}$ south of the Clipperton Fracture Zone (see the "Site U1335" chapter [Expedition 320/321 Scientists, $2010 b]$ ). This site is located on a broad plateau that parallels the Clipperton Fracture Zone and is within north-northeast-trending abyssal hill topography. Drilling recovered $417 \mathrm{~m}$ of biogenic sediment above basement. Here we report XRF scan data at $2.5 \mathrm{~cm}$ spacing for only part of the Site U1335 splice, from 0 to $302.66 \mathrm{mcd}$, covering the time span between $\sim 0$ and $20 \mathrm{Ma}$. Figure F2 shows $\mathrm{CaCO}_{3}$ normalized median-squared (NMS) data from 0 to $302.66 \mathrm{mcd}$.

\section{Site U1336}

Site U1336 $\left(7^{\circ} 42.067^{\prime} \mathrm{N}, 128^{\circ} 15.253^{\prime} \mathrm{W} ; 4286 \mathrm{~m}\right.$ water depth) is on $32 \mathrm{Ma}$ crust, $\sim 340 \mathrm{~km}$ northwest of Site U1335 (see the "Site U1336" chapter [Expedition 320/321 Scientists, 2010c]). The site is $\sim 30 \mathrm{~km}$ north of the center of the Clipperton Fracture Zone on a local high that is draped with $\sim 300$ m of sediment cover. The abyssal hills are oriented slightly west of due north. Coring revealed a hiatus at the top of the section to $\sim 12 \mathrm{Ma}$. Here we report XRF scan data at $2.5 \mathrm{~cm}$ spacing for only part of the Site U1336 splice, from 0 to 142.46 mcd. The Site U1336 scanning covers an age span roughly from $12 \mathrm{Ma}$ (the top of the sediment column) to $22 \mathrm{Ma}$. The splice used for this project is a revised version of the shipboard splice based on Wilkens et al. (2013). The revisions are due primarily to a poorly recovered interval at roughly 152 mcd that resulted in cores being appended to one another below this depth, rather than being tied together. The appended interval is below the scanned interval. Figure F3 shows

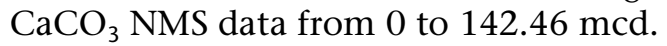

\section{Site U1337}

Site U1337 $\left(3^{\circ} 50.009^{\prime} \mathrm{N}, 123^{\circ} 12.352^{\prime} \mathrm{W} ; 4463 \mathrm{~m}\right.$ water depth) is on $\sim 24$ Ma crust between the Galapagos and Clipperton Fracture Zones (see the "Site U1337" chapter [Expedition 320/321 Scientists, 2010d]). The site is $\sim 390 \mathrm{~km}$ southeast of Site U1335, on a plateau between higher topography south of the site and a ridge to the north. Here we report XRF scan data for the entire Site U1337 splice, from 0 to $491.62 \mathrm{mcd}$, covering the entire spliced section. The upper sediment column (0-102.45 cm along the splice) was scanned at $5 \mathrm{~cm}$ intervals in order to tie to the highresolution scan $(0.5 \mathrm{~cm}$ interval) scanned by $\mathrm{K}$. Iijima (unpubl. data). The remainder of the sediment column was scanned at $2.5 \mathrm{~cm}$ spacing. The splice we use has some changes from the original shipboard splice due to core disturbance, especially at greater depth, and trouble with correlating the four cores that make up the Site U1337 splice. The splice is the revised splice reported in Wilkens et al. (2013). A depth of close to $490 \mathrm{mcd}$ was reached with only three gaps from the four holes. Figure F4 shows $\mathrm{CaCO}_{3}$ NMS from 0 to $475 \mathrm{mcd}$ for Site U1337.

\section{XRF scanning of Site U1335- U1337 spliced sections}

Sites U1335-U1337 exhibit the characteristic variations in sedimentary calcium carbonate content that result in the common seismic stratigraphy found throughout the equatorial Pacific east of Hawaii (Mayer et al., 1986). It has been difficult in the past to understand and determine what forcing mechanisms caused these carbonate cycles, which in turn caused these common seismic horizons, because they were poorly resolved by low-resolution shipboard sampling and analysis. Through the use of XRF scanning and discrete geochemical sampling to calibrate the XRF scan data, we can potentially determine calcium carbonate content, biogenic opal, biogenic barium (bio-Ba), and clay content in fine enough detail to better understand why sedimentary carbonate has varied in the equatorial Pacific.

XRF scanning can be used to study the biogeochemically active elements $\mathrm{Ca}, \mathrm{Si}$, and $\mathrm{Ba}$ in order to un- 
derstand changes in productivity (Lyle et al., 2012). These data can then be compared to changes in preservation to further understand changes in the overall carbon cycle. XRF scan data can also be used to measure aluminosilicate elements including $\mathrm{Al}, \mathrm{K}$, and $\mathrm{Ti}$ to better understand the dust input to the region (Lyle et al., 2012). Measuring redox-sensitive elements such as Fe and Mn gives information about the sedimentary redox environment, as well as a measure of distal hydrothermal plume deposition near the basement (Lyle et al., 2012).

XRF uses the characteristic fluorescence of elements exposed to high-energy X-ray illumination to estimate a sample's chemical composition. High-energy $\mathrm{X}$-ray photons eject inner-shell electrons from atoms being illuminated by the X-rays (Jansen et al., 1998), and the vacancies are filled by outer shell electrons. The excess energy is released as characteristic X-ray fluorescence energies for each element. The intensity of the fluorescence can be used to determine the abundance of different elements within the illuminated sample. With a scanning XRF, the detector is moved by a stepping system along a sediment core so that multiple measurements can be taken automatically (Richter et al., 2006).

\section{Methods and materials}

The spliced sediment columns from Sites U1335U1337 were scanned using the third-generation Avaatech XRF scanner at the IODP Gulf Coast Repository in College Station, Texas (USA) (odases.tamu.edu/index.php/research-facilities/). This XRF scanner is equipped with a Canberra XPIPS SDD, model SXD 15C-150-500 $150 \mathrm{eV}$ resolution X-ray detector and uses an X-ray tube with a Rhanode to generate the incident $\mathrm{X}$-rays that illuminate the sample. The XRF scanner is configured to analyze split sediment core halves for elements between $\mathrm{Al}$ and $\mathrm{U}$ on the periodic table. The $\mathrm{X}$-ray tube and detector are mounted on a moving track so that multiple spots at different depths can be analyzed on a split core during the scanning run, and multiple scans with different settings can be programmed to run automatically (Richter et al., 2006). There are, however, parameters controlled by the operator, such as X-ray tube current, voltage, measurement time (live time), filters, and area of X-ray illumination. The downcore position step is precise to 0.1 $\mathrm{mm}$.

\section{XRF scanning}

Sample spacing along each of the Site U1335 and U1336 core sections was set at $2.5 \mathrm{~cm}$. For Site U1337, sample spacing was set at $2.5 \mathrm{~cm}$ in the lower spliced section and $5 \mathrm{~cm}$ in the $0-110$ mcd section overlapping with K. Iijima's (unpubl. data) work. Two separate scans at different voltages were used on each section to gather all chemical data. The first scan was performed at $10 \mathrm{kV}$ with no filter for $\mathrm{Al}, \mathrm{Si}$, $\mathrm{S}, \mathrm{Cl}, \mathrm{K}, \mathrm{Ca}, \mathrm{Ti}, \mathrm{Mn}$, and $\mathrm{Fe}$. The measurement (live) time was set at $30 \mathrm{~s}$, and the X-ray tube current was set to at $500 \mu \mathrm{A}$. A second scan for Ba was performed at $50 \mathrm{kV}$ with a $\mathrm{Cu}$ filter, a measurement time of $10 \mathrm{~s}$, and the X-ray tube current set to $1000 \mu \mathrm{A}$. We lowered the X-ray tube current from $2000 \mu \mathrm{A}$ used for the Site U1338 scanning (Lyle et al., 2012) in order to preserve tube life and reduce the possibility of peak overlap problems. The core face illuminated by $\mathrm{X}$-rays was set at $1.0 \mathrm{~cm}$ in the downcore direction and $1.2 \mathrm{~cm}$ in the cross-core direction.

For the Site U1335 and U1337 cores, the scans were run down the center of the split core half $(6.8 \mathrm{~cm}$ total diameter). For the Site U1336 cores, the majority of the scans were run down the left side of the split core half to avoid the U-channel gap left by sampling for magnetostratigraphic analyses on the archive core prior to the XRF scanner runs. On the Uchanneled sections, the track in the XRF core scanner was offset $\sim 3 \mathrm{~cm}$ from the core's centerline. Additionally, cracks and holes from sampling in any of the cores were skipped if they corresponded to XRF sample spacing.

Each core was removed from refrigeration a minimum of $8 \mathrm{~h}$ prior to scanning to allow it to warm to room temperature. Each section was then covered $\sim 15$ min prior to scanning with $4 \mu \mathrm{m}$ thick Ultralene plastic film (SPEX Centriprep, Inc.) to protect the detector face from becoming contaminated during the scan. Following the methods in Lyle et al. (2012), the Ultralene film was placed over the core sections only once they had warmed to room temperature in order to avoid condensation building up on the film while the core sections warmed. Condensation buildup can lead to severely reduced light element (e.g., Al and Si) XRF peak areas because of the condensation absorbing the low-energy X-ray fluorescence coming back from the sediment to the detector (Tjallingii et al., 2007).

There were a few unexplained data dropouts that we found after plotting the data, one and occasionally two data points that were significantly lower than the data trends of the scan. Where we had overlapping data, we found these "events" on only one of the overlapping sections. We attribute the dropouts to an intermittent instrument failure and removed them from the data sets, including those shown in Tables T1, T2, and T3. We found 15 bad data points between 109 and 114 mcd in the Site U1336 core sections. Of the 15 bad data points found in the Site 
U1336 splice, 7 were outside of the splice, meaning they were in the overlapped section and would not have been included in the final splice even if they were kept, and 8 were within the splice, meaning that they would have been included in the final splice. All 15 bad data points were removed. Two additional bad data points were found in the Site U1336 splice at $\sim 32$ and $\sim 83 \mathrm{mcd}$. Both of these points were removed as well.

\section{Sediment splices}

XRF scanning was done to cores along the sediment splices, not to all sections recovered from the different holes at each site. Only core sections along the continuous spliced sections of Sites U1335 and U1336 were analyzed. We scanned every archive core half included on the Site U1336 and U1337 splice tables in 2011 and 2012 and completed the scanning of the Site U1335 spliced sections in January 2013. If the splice transferred from one hole to the next in the middle of a section, both sections were run in their entirety to provide enough overlap to allow for the record to be adjusted, if needed. In the Site U1337 splice, substantial changes have been made to the original continuous splice table, so additional sections were run to aid in revising that record.

Tables T1, T2, and T3 contain all of the data collected, not just the data that were used to construct the final splice (also see XRF in "Supplementary material"). Data incorporated into the splice are marked for easy extraction. Each table includes raw XRF peak area data and NMS reduced data for all three cores. Depths are indicated in meters below seafloor (mbsf), which is equivalent to core depth below seafloor (CSF-A), as well as converted to mcd, which is equivalent to CCSF-A. References to depth throughout this manuscript are in mcd. Medians of shipboard geochemical data and calculated area medians, both used in scaling and normalizing the raw XRF area data, are presented in Table T4. For each element in Tables T1, T2, and T3, we have listed the raw XRF peak area, the median-scaled total, and the NMS data as described below.

\section{XRF data reduction}

Data reduction was accomplished by a three-step method generally following the methods in Lyle et al. (2012). In the first step, which is an addition to the two-step reduction method developed in Lyle et al. (2012), negative peak area values were set to zero and removed from further calculations. Negative peak areas can appear where there are overlapping peaks and the elemental concentration is low. In this case, the measured data are actually below the modeled energy curve at 0 concentration.
Second, data were scaled by the median shipboardmeasured bulk sediment elemental composition in order to scale elemental peak areas into typical ranges of sediment composition. Finally, the scaled components were summed and normalized to $100 \%$ in order to account for changes in porosity and cracks throughout the core sections. Only sections used in the final splices were used in calculating the area medians, so changes to the final splices may require recalculation of those medians and therefore NMS values.

To scale the XRF data, the following equation from Lyle et al. (2012), was used:

$$
\mathrm{S}_{\mathrm{e}}=\text { Med } \%_{\mathrm{e}} \times\left(\text { PeakArea }_{\mathrm{e}} / \text { PeakArea }_{\mathrm{e}, \mathrm{med}}\right),
$$

where $\mathrm{S}_{\mathrm{e}}$ is the elemental scaling, Med $\%_{\mathrm{e}}$ is the median weight percent of a sedimentary component, which was the oxide for each element (e.g., for $\mathrm{Al}$, we used the oxide $\mathrm{Al}_{2} \mathrm{O}_{3}$, and for $\mathrm{Ca}, \mathrm{CaCO}_{3}$ ) from shipboard geochemical data, PeakArea $\mathrm{e}_{\mathrm{e}}$ is the measured elemental peak area in the sample, and PeakArea $_{\mathrm{e}, \mathrm{med}}$ is the median peak area over the data set.

To normalize the scaled XRF data, thereby removing the volume effect, each component (C) was multiplied by $100 /$ (raw sum) to bring the total sum of components to $100 \%$, rather than the lower value that results from high porosity or cracks:

$$
\mathrm{NMS}_{\mathrm{c}}=\mathrm{C} \times 100 /(\text { raw sum }),
$$

where $\mathrm{NMS}_{\mathrm{c}}$ is the normalized median-scaled value for the component and $\mathrm{C}$ is the median-scaled value of the component. The sedimentary components in these data sets are $\mathrm{Al}_{2} \mathrm{O}_{3}, \mathrm{SiO}_{2}, \mathrm{~K}_{2} \mathrm{O}, \mathrm{CaCO}_{3}, \mathrm{TiO}_{2}$, $\mathrm{MnO}, \mathrm{Fe}_{2} \mathrm{O}_{3}$, and $\mathrm{BaSO}_{4}$. Normalization minimizes the high-frequency noise produced from greater porosity in the shallower portions of the splice and increased cracks and uneven surfaces in the lower sections of the splice.

Through the scaling and normalization process, we developed a way to quantitatively estimate sediment concentration based on XRF scans. XRF NMS estimates, however, can have significant errors if the model of sediment composition (the "type" of sediment composition) used is very different from the actual sediment composition. In other words, errors will result if the model sediment components do not match those within the actual sediment (e.g., if $\mathrm{Ca}$ is found in a clay and thus would be better represented by a $\mathrm{CaO}$ component) or if a major element found in the sediment is not included in the model. Despite these issues, NMS data are significantly better to study the changes in sediment composition than the raw XRF peak area because the porosity effect is re- 
moved. Raw peak area data can have larger relative errors because of the differences in porosity between the sediment layers and from technical problems landing the detector on a flat sediment surface. Very dry and cracked sediment can cause the detector to not land flat against the sediment while collecting peak area data, or to have small cracks included in the scan area, lowering the raw counts. Figure F5 shows the raw median-scaled $\mathrm{CaCO}_{3}$, the NMS Ca$\mathrm{CO}_{3}$, and discrete $\mathrm{CaCO}_{3}$ for Sites U1335-U1337. Scaling and normalization reduced apparent noise in the XRF data and made the total range more similar to the variability seen in the shipboard data.

The NMS data can be easily calibrated to estimated sediment composition by analyzing a small set of check data that spans the typical range of sediment values and correlating the NMS data to the discrete measurements (Lyle and Backman, 2013).

\section{Results}

One of the important uses of XRF scanning is to be able to produce high-resolution data sets, such as the $>19$ m.y. sediment records from Sites U1335 and U1337. The Site U1336 sediment record spans $\sim 12.12$ to $20 \mathrm{Ma}$. Figure F6 shows the NMS time series of $\mathrm{CaCO}_{3} \mathrm{NMS}$ data at all three sites examined in this study. Also shown are biostratigraphic and magnetostratigraphic tie lines used to compare the records at each site to one another. Table T5 provides the depths, ages, and types of stratigraphic tie points shown in the figure. The upper section of the Site U1337 splice is expanded when compared with that of the Site U1335 splice because Site U1337 has been in closer proximity to the Equator since $12 \mathrm{Ma}\left(1.1^{\circ}\right.$ $3.8^{\circ} \mathrm{N}$ ) versus $2.4^{\circ}-5.3^{\circ} \mathrm{N}$ for Site U1335. The closer proximity to the Equator exposed Site U1337 to higher sediment deposition. As the sites moved further from the Equator, they received less sediment deposition, as illustrated in the extreme by the hiatus from $\sim 0$ to $12 \mathrm{Ma}$ at Site U1336.

Figure F7 shows all three sites, again with bio- and magnetostratigraphic tie lines, focusing on a very prominent $\mathrm{CaCO}_{3}$ low that peaks at $\sim 17 \mathrm{Ma}$ and begins at $\sim 17.7 \mathrm{Ma}$. The age is earlier than the usually assumed start of the Monterey carbon isotope excursion (16.9-13.7 Ma; Holbourn et al., 2007) but older than that of the Columbia River basalt flood basalt eruption ( 16.8-5.5 Ma; Reidel and Tolan, 2013), which could have released significant amount of deep $\mathrm{CO}_{2}$ that potentially could have caused added carbonate dissolution in the oceans. The peak $\mathrm{CaCO}_{3}$ dissolution occurs at or slightly after the onset of the southeast Oregon eruptions that began the deposi- tion of the Columbia River basalts in North America (16.8-16.6 Ma; Barry et al., 2013). The flood basalt deposition and the equatorial Pacific dissolution event can only be linked if volatile degassing is associated with the emplacement of the magma in the crust, not the eruption.

The 17 Ma carbonate dissolution event lasted $\sim 1$ m.y. and is strongly influenced by orbital insolation changes. The $\mathrm{CaCO}_{3}$ analyses indicate cyclicity on an approximately 100,000 y timescale.

\section{Conclusions}

We present scanning XRF data along the splices of Sites U1335-U1337 (41,925 total sample measurements, with 33,739 samples along the three splices) and show their use in exploring the history of the equatorial Pacific productivity zone. We found we could scan the splices for $\mathrm{Al}, \mathrm{Si}, \mathrm{K}, \mathrm{Ca}, \mathrm{Ti}, \mathrm{Mn}, \mathrm{Fe}$, and $\mathrm{Ba}$ in a reasonably short amount of time, averaging slightly more than $1 \mathrm{~h}$ per section. The raw data, however, are a volume measurement and must be scaled, normalized, and eventually calibrated to make an estimate of sediment composition. The NMS data-reduction process described helps to make correlations between raw peak areas and measured chemical compositions more linear so that calibration is easier. To achieve good results, care must be taken to choose a sediment compositional model (median composition and type of sediment components) that is similar to the sediment under investigation. Calibration is the final step in converting XRF scan data to a compositional estimate. Ideally, enough samples are measured by discrete geochemical analysis that some of the data are left out of the calibration and can be used to check the data.

\section{Acknowledgments}

We thank Integrated Ocean Drilling Program (IODP) Expedition 320/321 party members, IODP, and the IODP Gulf Coast Repository (GCR) for providing samples and assistance during XRF analysis, as well as all the effort they put in to properly collect and archive the Site U1335-U1337 sediment cores. Additionally, we would like to thank the reviewers for their constructive comments and assistance. We also acknowledge the Ocean Drilling and Sustainable Earth Sciences (ODASES) program at Texas A\&M University for acquiring the Avaatech XRF scanner for the GCR, as well as for fellowship funding for J. Shackford. Scanning and analysis were paid for by a United States Advisory Committee for Scientific Ocean Drilling postcruise grant and by National Science Foundation grant OCE-0962184 to M. Lyle. 


\section{References}

Barry, T.L., Self, S., Kelley, S.P., Reidel, S., Hooper, P., and Widdowson, M., 2010. New ${ }^{40} \mathrm{Ar} /{ }^{39} \mathrm{Ar}$ dating of the Grande Ronde lavas, Columbia River basalts, USA: implications for duration of flood basalt eruption episodes. Lithos, 118(3-4):213-222. doi:10.1016/ j.lithos.2010.03.014

Expedition 320/321 Scientists, 2010a. Methods. In Pälike, H., Lyle, M., Nishi, H., Raffi, I., Gamage, K., Klaus, A., and the Expedition 320/321 Scientists, Proc. IODP, 320/ 321: Tokyo (Integrated Ocean Drilling Program Management International, Inc.). doi:10.2204/ iodp.proc.320321.102.2010

Expedition 320/321 Scientists, 2010b. Site U1335. In Pälike, H., Lyle, M., Nishi, H., Raffi, I., Gamage, K., Klaus, A., and the Expedition 320/321 Scientists, Proc. IODP, 320/321: Tokyo (Integrated Ocean Drilling Program Management International, Inc.). doi:10.2204/ iodp.proc.320321.107.2010

Expedition 320/321 Scientists, 2010c. Site U1336. In Pälike, H., Lyle, M., Nishi, H., Raffi, I., Gamage, K., Klaus, A., and the Expedition 320/321 Scientists, Proc. IODP, 320/321: Tokyo (Integrated Ocean Drilling Program Management International, Inc.). doi:10.2204/ iodp.proc.320321.108.2010

Expedition 320/321 Scientists, 2010d. Site U1337. In Pälike, H., Lyle, M., Nishi, H., Raffi, I., Gamage, K., Klaus, A., and the Expedition 320/321 Scientists, Proc. IODP, 320/321: Tokyo (Integrated Ocean Drilling Program Management International, Inc.). doi:10.2204/ iodp.proc.320321.109.2010

Holbourn, A., Kuhnt, W., Schulz, M., Flores, J.-A., and Andersen, N., 2007. Orbitally-paced climate evolution during the middle Miocene "Monterey" carbon-isotope excursion. Earth Planet. Sci. Lett., 261(3-4):534-550. doi:10.1016/j.epsl.2007.07.026

Jansen, J.H.F., Van der Gaast, S.J., Koster, B., and Vaars, A.J., 1998. CORTEX, a shipboard XRF-scanner for element analyses in split sediment cores. Mar. Geol., 151(14):143-153. doi:10.1016/S0025-3227(98)00074-7

Lyle, M., and Backman, J., 2013. Data report: calibration of XRF-estimated $\mathrm{CaCO}_{3}$ along the Site U1338 splice. In Pälike, H., Lyle, M., Nishi, H., Raffi, I., Gamage, K., Klaus, A., and the Expedition 320/321 Scientists, Proc. IODP, 320/321: Tokyo (Integrated Ocean Drilling Program Management International, Inc.). doi:10.2204/ iodp.proc.320321.205.2013

Lyle, M., Olivarez Lyle, A., Gorgas, T., Holbourn, A., Westerhold, T., Hathorne, E., Kimoto, K., and Yama- moto, S., 2012. Data report: raw and normalized elemental data along the Site U1338 splice from X-ray fluorescence scanning. In Pälike, H., Lyle, M., Nishi, H., Raffi, I., Gamage, K., Klaus, A., and the Expedition 320/ 321 Scientists, Proc. IODP, 320/321: Tokyo (Integrated Ocean Drilling Program Management International, Inc.). doi:10.2204/iodp.proc.320321.203.2012

Mayer, L.A., Shipley, T.H., and Winterer, E.L., 1986. Equatorial Pacific seismic reflectors as indicators of global oceanographic events. Science, 233(4765):761-764. doi:10.1126/science.233.4765.761

Pälike, H., Nishi, H., Lyle, M., Raffi, I., Gamage, K., Klaus, A., and the Expedition 320/321 Scientists, 2010. Expedition 320/321 summary. In Pälike, H., Lyle, M., Nishi, H., Raffi, I., Gamage, K., Klaus, A., and the Expedition 320/ 321 Scientists, Proc. IODP, 320/321: Tokyo (Integrated Ocean Drilling Program Management International, Inc.). doi:10.2204/iodp.proc.320321.101.2010

Reidel, S.P., and Tolan, T.L., 2013. The late Cenozoic evolution of the Columbia River system in the Columbia River flood basalt province. In Reidel, S.P., Camp, V.E., Ross, M.E., Wolff, J.A., Martin, B.S., Tolan, T.L., and Wells, R.E. (Eds.), The Columbia River Flood Basalt Province. Spec. Pap.-Geol. Soc. Am., 497:201-230.

Richter, T.O., van der Gaast, S., Koster, B., Vaars, A., Gieles, R., de Stigter, H.C., De Haas, H., and van Weering, T.C.E., 2006. The Avaatech XRF Core Scanner: technical description and applications to NE Atlantic sediments. In Rothwell, R.G. (Ed.), New Techniques in Sediment Core Analysis. Geol. Soc. Spec. Publ., 267(1):39-50. doi:10.1144/GSL.SP.2006.267.01.03

Tjallingii, R., Röhl, U., Kölling, M., and Bickert, T., 2007. Influence of the water content on X-ray fluorescence core-scanning measurements in soft marine sediments. Geochem., Geophys., Geosyst., 8(2):Q02004. doi:10.1029/ 2006GC001393

Wilkens, R.H., Dickens, G.R., Tian, J., Backman, J., and the Expedition 320/321 Scientists, 2013. Data report: revised composite depth scales for Sites U1336, U1337, and U1338. In Pälike, H., Lyle, M., Nishi, H., Raffi, I., Gamage, K., Klaus, A., and the Expedition 320/321 Scientists, Proc. IODP, 320/321: Tokyo (Integrated Ocean Drilling Program Management International, Inc.). doi:10.2204/iodp.proc.320321.209.2013

Initial receipt: 20 August 2013

Acceptance: 7 May 2014

Publication: 15 August 2014 
Figure F1. Expedition 320/321 sites and Pacific Equatorial Age Transect drilling locations. Black circles are other sites drilled during Integrated Ocean Drilling Program, Deep Sea Drilling Project, and Ocean Drilling Program. F.Z. = fracture zone. From the "Expedition 320/321 summary" chapter (Pälike et al., 2010).

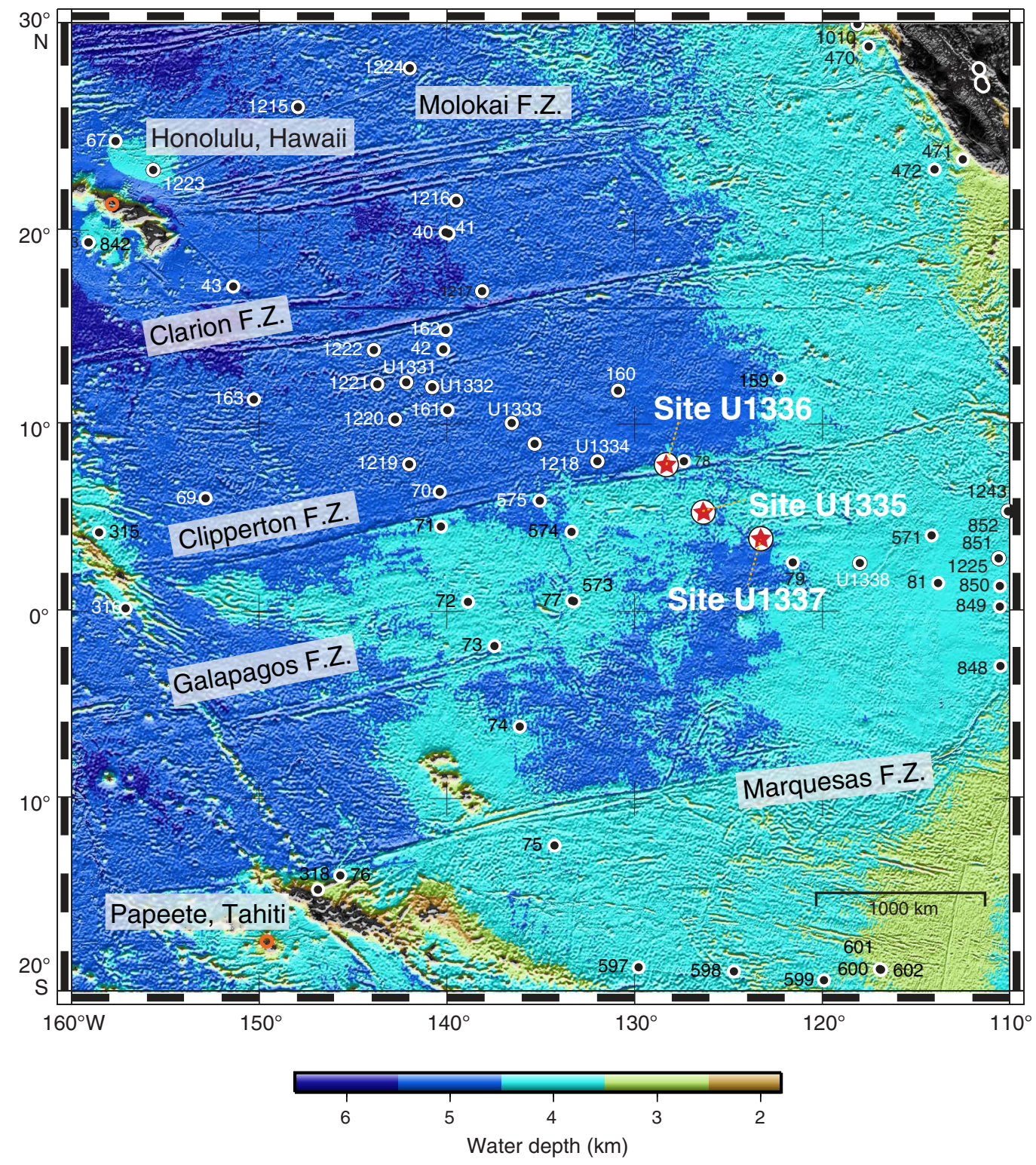


Figure F2. $\mathrm{CaCO}_{3}$ normalized median-squared (NMS) values vs. depth, Site U1335.

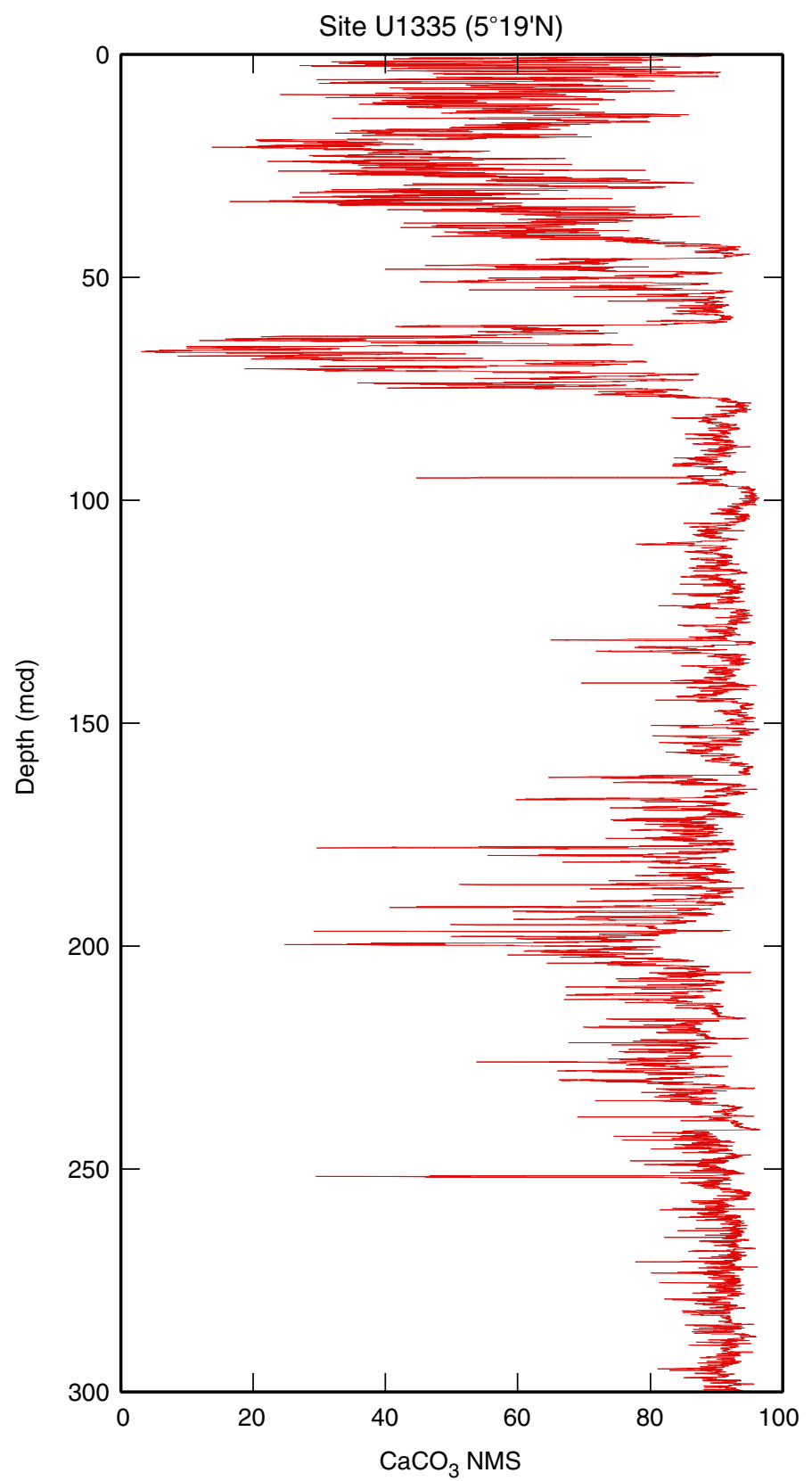


Figure F3. $\mathrm{CaCO}_{3}$ normalized median-squared (NMS) values vs. depth, Site U1336.

Site U1336 $\left(7^{\circ} 42^{\prime} \mathrm{N}\right)$

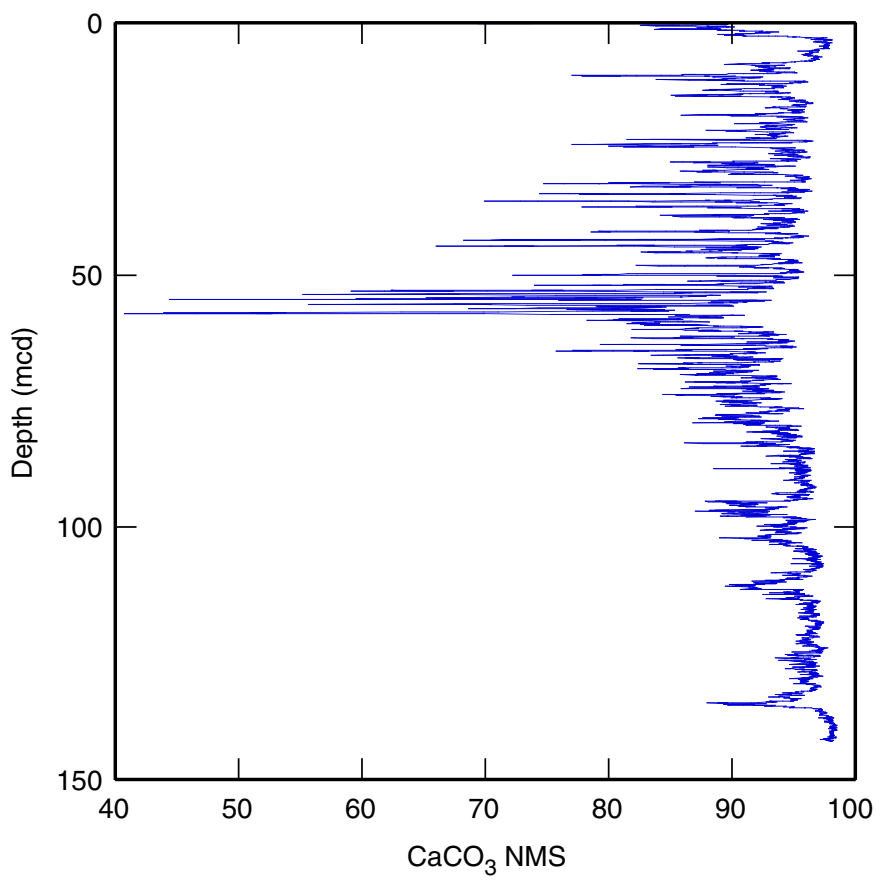


Figure F4. $\mathrm{CaCO}_{3}$ normalized median-squared (NMS) values vs. depth, Site U1337.

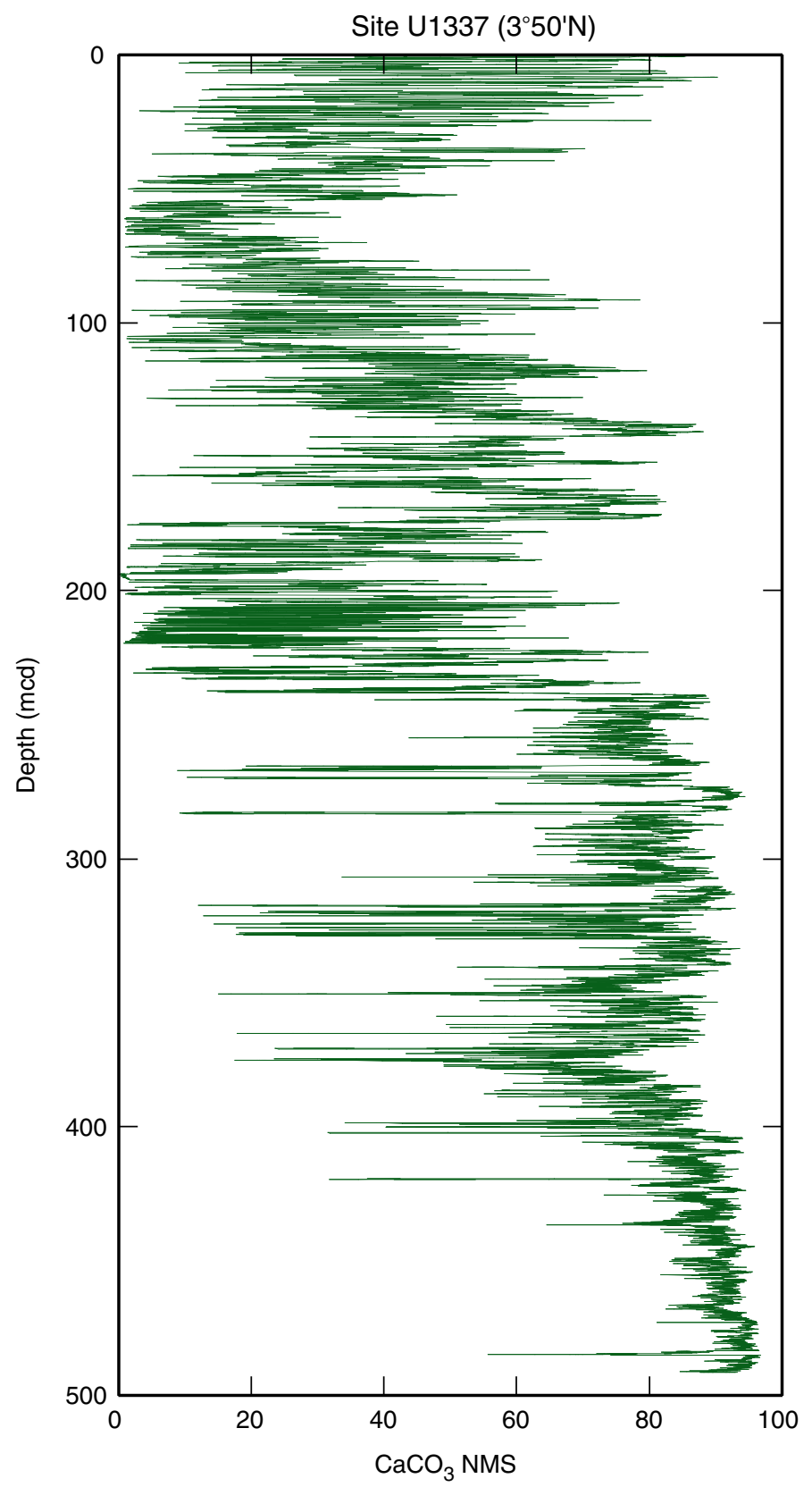


Figure F5. Comparison of raw median-scaled $\mathrm{CaCO}_{3}$ with normalized median-squared (NMS) $\mathrm{CaCO}_{3}$ estimates, discrete shipboard $\mathrm{CaCO}_{3}$, and discrete shore-based $\mathrm{CaCO}_{3}$ (Site U1337 only; J. Shackford, unpubl. data). Normalizing the sum of components to $100 \%$ removes the variability as well as corrects for volume effects.
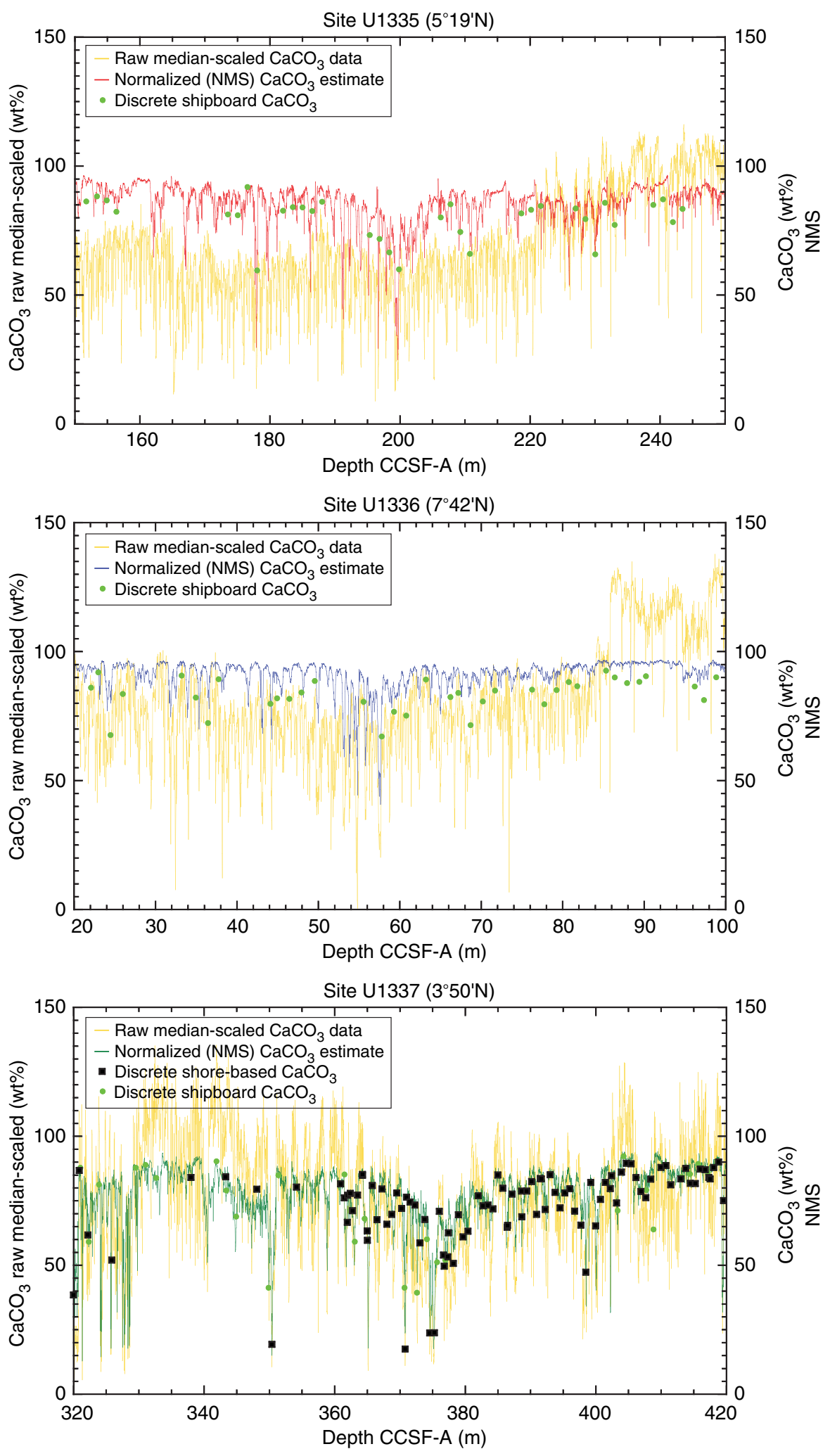
Figure F6. $\mathrm{CaCO}_{3}$ normalized median-squared (NMS) values and stratigraphic correlation between Sites U1335, U1336, and U1337. Ages are shown above the stratigraphic tie lines.

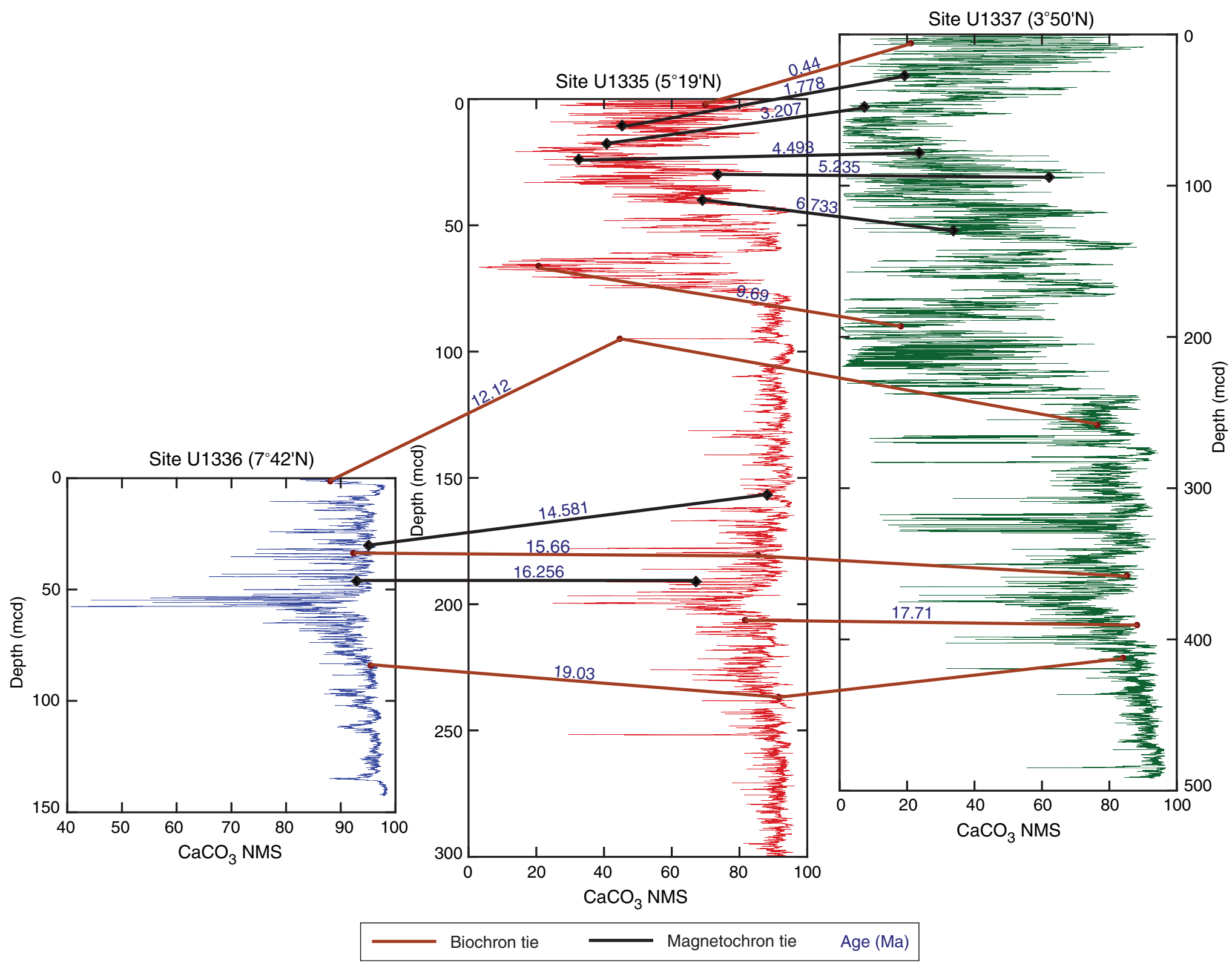


Figure F7. $\mathrm{CaCO}_{3}$ normalized median-squared (NMS) values and stratigraphic correlation between Sites U1335, U1336, and U1337 for the period of time surrounding the $17 \mathrm{Ma} \mathrm{CaCO}_{3}$ dissolution event. Ages are shown above the stratigraphic tie lines. Additionally, the primary CaCO ${ }_{3}$ dissolution signal of the 17 Ma event is outlined by a yellow box.

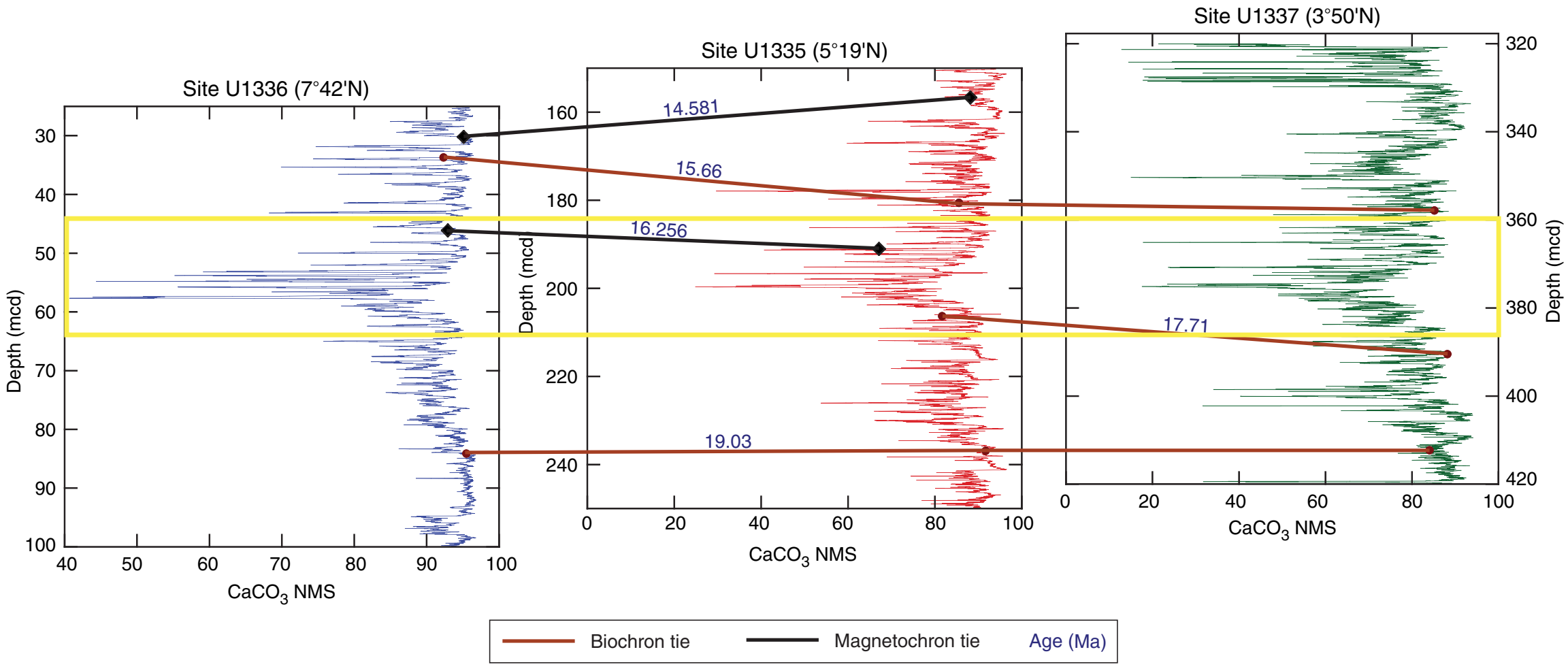


Table T1. Raw X-ray fluorescence peak area data and calculated normalized median-squared (NMS) spliced data for all scans, Site U1335.

\begin{tabular}{|c|c|c|c|c|c|c|c|c|c|c|c|c|}
\hline $\begin{array}{l}\text { Core, } \\
\text { section }\end{array}$ & $\begin{array}{l}\text { Depth } \\
\text { in section } \\
(\mathrm{mm})\end{array}$ & $\begin{array}{l}\text { Measurement } \\
\text { date }\end{array}$ & $\begin{array}{l}\text { Depth (mbsf } \\
\text { [m revised } \\
\text { CSF-A]) }\end{array}$ & $\begin{array}{l}\text { Depth }(\mathrm{mcd} \\
\text { [m revised } \\
\text { CCSF-A]) }\end{array}$ & $\begin{array}{l}\text { Raw } \\
\text { component } \\
\text { sum } \\
(\%)\end{array}$ & $\begin{array}{c}\text { Al } \\
\text { area }\end{array}$ & $\begin{array}{c}\text { Al } \\
\text { median- } \\
\text { scale }\end{array}$ & $\begin{array}{l}\mathrm{Al}_{2} \mathrm{O}_{3} \\
\mathrm{NMS}\end{array}$ & $\begin{array}{c}\mathrm{Si} \\
\text { area }\end{array}$ & $\begin{array}{l}\text { Si } \\
\text { median- } \\
\text { scale }\end{array}$ & $\begin{array}{l}\mathrm{SiO}_{2} \\
\mathrm{NMS}\end{array}$ & $\begin{array}{c}\mathrm{S} \\
\text { area }\end{array}$ \\
\hline \multicolumn{13}{|c|}{ 320-U1335B- } \\
\hline $1 \mathrm{H}-1^{*}$ & 25 & $1 / 12 / 2013$ & 0.025 & 0.025 & 36.67 & 64 & 0.12 & 0.32 & 21,039 & 5.79 & 15.78 & 3,461 \\
\hline $1 \mathrm{H}-1^{*}$ & 50 & $1 / 12 / 2013$ & 0.05 & 0.05 & 31.36 & 69 & 0.12 & 0.40 & 16,866 & 4.64 & 14.79 & 3,066 \\
\hline $1 \mathrm{H}-1^{*}$ & 75 & $1 / 12 / 2013$ & 0.075 & 0.075 & 36.51 & 16 & 0.03 & 0.08 & 15,265 & 4.20 & 11.50 & 3,076 \\
\hline $1 \mathrm{H}-1^{*}$ & 100 & $1 / 12 / 2013$ & 0.1 & 0.1 & 45.57 & 0 & 0.00 & 0.00 & 18,783 & 5.17 & 11.34 & 2,734 \\
\hline $1 \mathrm{H}-1^{*}$ & 125 & $1 / 12 / 2013$ & 0.125 & 0.125 & 47.06 & 0 & 0.00 & 0.00 & 20,625 & 5.67 & 12.05 & 3,361 \\
\hline $1 \mathrm{H}-1^{*}$ & 150 & $1 / 12 / 2013$ & 0.15 & 0.15 & 45.69 & 55 & 0.10 & 0.22 & 18,874 & 5.19 & 11.36 & 3,609 \\
\hline $1 \mathrm{H}-1^{*}$ & 175 & $1 / 12 / 2013$ & 0.175 & 0.175 & 65.34 & 14 & 0.03 & 0.04 & 29,423 & 8.09 & 12.39 & 5,432 \\
\hline $1 \mathrm{H}-1^{*}$ & 200 & $1 / 12 / 2013$ & 0.2 & 0.2 & 71.57 & 413 & 0.75 & 1.04 & 33,660 & 9.26 & 12.94 & 5,581 \\
\hline $1 \mathrm{H}-1^{*}$ & 225 & $1 / 12 / 2013$ & 0.225 & 0.225 & 70.91 & 107 & 0.19 & 0.27 & 30,863 & 8.49 & 11.97 & 6,382 \\
\hline $1 \mathrm{H}-1^{*}$ & 250 & $1 / 12 / 2013$ & 0.25 & 0.25 & 75.52 & 49 & 0.09 & 0.12 & 24,797 & 6.82 & 9.03 & 5,186 \\
\hline $1 \mathrm{H}-1^{*}$ & 275 & $1 / 12 / 2013$ & 0.275 & 0.275 & 72.30 & 286 & 0.52 & 0.72 & 25,641 & 7.05 & 9.75 & 5,439 \\
\hline $1 \mathrm{H}-1^{*}$ & 300 & $1 / 12 / 2013$ & 0.3 & 0.3 & 70.58 & 0 & 0.00 & 0.00 & 21,389 & 5.88 & 8.34 & 5,365 \\
\hline $1 \mathrm{H}-1^{*}$ & 325 & $1 / 12 / 2013$ & 0.325 & 0.325 & 65.62 & 0 & 0.00 & 0.00 & 20,307 & 5.59 & 8.51 & 5,204 \\
\hline $1 \mathrm{H}-1^{*}$ & 350 & $1 / 12 / 2013$ & 0.35 & 0.35 & 78.66 & 260 & 0.47 & 0.60 & 25,007 & 6.88 & 8.74 & 5,417 \\
\hline $1 \mathrm{H}-1^{*}$ & 375 & $1 / 12 / 2013$ & 0.375 & 0.375 & 74.17 & 185 & 0.33 & 0.45 & 23,231 & 6.39 & 8.61 & 6,270 \\
\hline $1 \mathrm{H}-1^{*}$ & 400 & $1 / 12 / 2013$ & 0.4 & 0.4 & 72.52 & 180 & 0.33 & 0.45 & 24,736 & 6.80 & 9.38 & 5,590 \\
\hline $1 \mathrm{H}-1^{*}$ & 425 & $1 / 12 / 2013$ & 0.425 & 0.425 & 65.83 & 114 & 0.21 & 0.31 & 23,627 & 6.50 & 9.87 & 5,521 \\
\hline $1 \mathrm{H}-1^{*}$ & 450 & $1 / 12 / 2013$ & 0.45 & 0.45 & 70.27 & 118 & 0.21 & 0.30 & 24,837 & 6.83 & 9.72 & 5,400 \\
\hline $1 \mathrm{H}-1^{*}$ & 475 & $1 / 12 / 2013$ & 0.475 & 0.475 & 68.32 & 286 & 0.52 & 0.76 & 26,155 & 7.19 & 10.53 & 5,740 \\
\hline $1 \mathrm{H}-1^{*}$ & 500 & $1 / 12 / 2013$ & 0.5 & 0.5 & 50.10 & 0 & 0.00 & 0.00 & 17,595 & 4.84 & 9.66 & 5,113 \\
\hline $1 \mathrm{H}-1^{*}$ & 525 & $1 / 12 / 2013$ & 0.525 & 0.525 & 51.57 & 150 & 0.27 & 0.53 & 20,473 & 5.63 & 10.92 & 5,525 \\
\hline $1 \mathrm{H}-1^{*}$ & 550 & $1 / 12 / 2013$ & 0.55 & 0.55 & 49.29 & 192 & 0.35 & 0.71 & 22,399 & 6.16 & 12.50 & 5,070 \\
\hline $1 \mathrm{H}-1^{*}$ & 575 & $1 / 12 / 2013$ & 0.575 & 0.575 & 43.06 & 217 & 0.39 & 0.91 & 21,885 & 6.02 & 13.98 & 4,324 \\
\hline $1 \mathrm{H}-1^{*}$ & 600 & $1 / 12 / 2013$ & 0.6 & 0.6 & 49.98 & 634 & 1.15 & 2.30 & 32,509 & 8.94 & 17.89 & 6,279 \\
\hline $1 \mathrm{H}-1^{*}$ & 625 & $1 / 12 / 2013$ & 0.625 & 0.625 & 44.56 & 303 & 0.55 & 1.23 & 23,529 & 6.47 & 14.52 & 6,344 \\
\hline $1 \mathrm{H}-1^{*}$ & 650 & $1 / 12 / 2013$ & 0.65 & 0.65 & 36.88 & 706 & 1.28 & 3.47 & 29,336 & 8.07 & 21.88 & 7,720 \\
\hline $1 \mathrm{H}-1^{*}$ & 675 & $1 / 12 / 2013$ & 0.675 & 0.675 & 46.17 & 763 & 1.38 & 2.99 & 34,085 & 9.37 & 20.31 & 7,016 \\
\hline $1 \mathrm{H}-1^{*}$ & 700 & $1 / 12 / 2013$ & 0.7 & 0.7 & 36.02 & 765 & 1.38 & 3.84 & 35,422 & 9.74 & 27.05 & 8,347 \\
\hline $1 \mathrm{H}-1^{*}$ & 725 & $1 / 12 / 2013$ & 0.725 & 0.725 & 45.37 & 831 & 1.50 & 3.32 & 37,437 & 10.30 & 22.70 & 7,382 \\
\hline $1 \mathrm{H}-1^{*}$ & 750 & $1 / 12 / 2013$ & 0.75 & 0.75 & 44.58 & 1,500 & 2.72 & 6.09 & 53,036 & 14.59 & 32.72 & 8,838 \\
\hline $1 \mathrm{H}-1^{*}$ & 775 & $1 / 12 / 2013$ & 0.775 & 0.775 & 45.90 & 1,905 & 3.45 & 7.51 & 58,178 & 16.00 & 34.86 & 8,893 \\
\hline $1 \mathrm{H}-1^{*}$ & 800 & $1 / 12 / 2013$ & 0.8 & 0.8 & 52.74 & 1,740 & 3.15 & 5.97 & 53,884 & 14.82 & 28.10 & 8,585 \\
\hline $1 \mathrm{H}-1^{*}$ & 825 & $1 / 12 / 2013$ & 0.825 & 0.825 & 44.05 & 1,680 & 3.04 & 6.90 & 49,506 & 13.62 & 30.91 & 8,920 \\
\hline $1 \mathrm{H}-1^{*}$ & 850 & $1 / 12 / 2013$ & 0.85 & 0.85 & 39.81 & 1,704 & 3.08 & 7.75 & 49,828 & 13.70 & 34.42 & 8,610 \\
\hline $1 \mathrm{H}-1^{*}$ & 875 & $1 / 12 / 2013$ & 0.875 & 0.875 & 24.91 & 565 & 1.02 & 4.11 & 26,473 & 7.28 & 29.23 & 4,699 \\
\hline $1 \mathrm{H}-1^{*}$ & 900 & 1/12/2013 & 0.9 & 0.9 & 23.76 & 448 & 0.81 & 3.41 & 23,878 & 6.57 & 27.64 & 4,458 \\
\hline $1 \mathrm{H}-1^{*}$ & 925 & $1 / 12 / 2013$ & 0.925 & 0.925 & 36.49 & 1,022 & 1.85 & 5.07 & 32,938 & 9.06 & 24.83 & 6,574 \\
\hline $1 \mathrm{H}-1^{*}$ & 950 & $1 / 12 / 2013$ & 0.95 & 0.95 & 22.02 & 746 & 1.35 & 6.13 & 26,576 & 7.31 & 33.19 & 4,439 \\
\hline $1 \mathrm{H}-1^{*}$ & 975 & $1 / 12 / 2013$ & 0.975 & 0.975 & 44.86 & 1,362 & 2.47 & 5.50 & 47,109 & 12.96 & 28.88 & 8,053 \\
\hline $1 \mathrm{H}-1^{*}$ & 1,000 & $1 / 12 / 2013$ & 1 & 1 & 53.54 & 1,398 & 2.53 & 4.73 & 44,589 & 12.26 & 22.91 & 7,993 \\
\hline $1 \mathrm{H}-1^{*}$ & 1,025 & $1 / 12 / 2013$ & 1.025 & 1.025 & 65.16 & 656 & 1.19 & 1.82 & 40,361 & 11.10 & 17.04 & 6,054 \\
\hline $1 \mathrm{H}-1^{*}$ & 1,050 & $1 / 12 / 2013$ & 1.05 & 1.05 & 65.54 & 522 & 0.95 & 1.44 & 36,649 & 10.08 & 15.38 & 6,243 \\
\hline $1 \mathrm{H}-1^{*}$ & 1,075 & $1 / 12 / 2013$ & 1.075 & 1.075 & 39.44 & 433 & 0.78 & 1.99 & 34,730 & 9.55 & 24.22 & 8,720 \\
\hline $1 \mathrm{H}-1^{*}$ & 1,100 & $1 / 12 / 2013$ & 1.1 & 1.1 & 64.91 & 527 & 0.95 & 1.47 & 36,322 & 9.99 & 15.39 & 6,415 \\
\hline $1 \mathrm{H}-1^{*}$ & 1,125 & $1 / 12 / 2013$ & 1.125 & 1.125 & 71.12 & 472 & 0.85 & 1.20 & 33,070 & 9.10 & 12.79 & 5,998 \\
\hline $1 \mathrm{H}-1^{*}$ & 1,150 & $1 / 12 / 2013$ & 1.15 & 1.15 & 76.64 & 581 & 1.05 & 1.37 & 37,704 & 10.37 & 13.53 & 5,236 \\
\hline $1 \mathrm{H}-1^{*}$ & 1,175 & $1 / 12 / 2013$ & 1.175 & 1.175 & 69.60 & 396 & 0.72 & 1.03 & 33,384 & 9.18 & 13.19 & 5,649 \\
\hline $1 \mathrm{H}-1^{*}$ & 1,200 & $1 / 12 / 2013$ & 1.2 & 1.2 & 65.85 & 381 & 0.69 & 1.05 & 31,416 & 8.64 & 13.12 & 5,053 \\
\hline $1 \mathrm{H}-1^{*}$ & 1,225 & $1 / 12 / 2013$ & 1.225 & 1.225 & 68.61 & 495 & 0.90 & 1.31 & 37,320 & 10.26 & 14.96 & 6,187 \\
\hline $1 \mathrm{H}-1^{*}$ & 1,250 & $1 / 12 / 2013$ & 1.25 & 1.25 & 58.88 & 635 & 1.15 & 1.95 & 39,681 & 10.91 & 18.54 & 6,613 \\
\hline $1 \mathrm{H}-1^{*}$ & 1,275 & $1 / 12 / 2013$ & 1.275 & 1.275 & 51.69 & 506 & 0.92 & 1.77 & 34,246 & 9.42 & 18.22 & 6,528 \\
\hline $1 \mathrm{H}-1^{*}$ & 1,300 & $1 / 12 / 2013$ & 1.3 & 1.3 & 27.08 & 182 & 0.33 & 1.22 & 15,827 & 4.35 & 16.07 & 2,722 \\
\hline $1 \mathrm{H}-1^{*}$ & 1,325 & $1 / 12 / 2013$ & 1.325 & 1.325 & 30.94 & 27 & 0.05 & 0.16 & 16,228 & 4.46 & 14.43 & 3,454 \\
\hline $1 \mathrm{H}-1^{*}$ & 1,350 & $1 / 12 / 2013$ & 1.35 & 1.35 & 43.13 & 2,485 & 4.50 & 10.43 & 21,238 & 5.84 & 13.54 & 8,300 \\
\hline $1 \mathrm{H}-1^{*}$ & 1,375 & $1 / 12 / 2013$ & 1.375 & 1.375 & 31.15 & 439 & 0.79 & 2.55 & 23,170 & 6.37 & 20.46 & 4,111 \\
\hline $1 \mathrm{H}-1^{*}$ & 1,400 & $1 / 12 / 2013$ & 1.4 & 1.4 & 49.07 & 1,009 & 1.83 & 3.72 & 41,887 & 11.52 & 23.48 & 6,968 \\
\hline $1 \mathrm{H}-1^{*}$ & 1,425 & $1 / 12 / 2013$ & 1.425 & 1.425 & 50.91 & 1,432 & 2.59 & 5.09 & 48,055 & 13.22 & 25.96 & 7,779 \\
\hline $1 \mathrm{H}-1^{*}$ & 1,450 & $1 / 12 / 2013$ & 1.45 & 1.45 & 50.27 & 2,033 & 3.68 & 7.32 & 57,543 & 15.83 & 31.48 & 9,262 \\
\hline $1 \mathrm{H}-1^{*}$ & 1,475 & $1 / 12 / 2013$ & 1.475 & 1.475 & 16.98 & 352 & 0.64 & 3.75 & 19,565 & 5.38 & 31.70 & 3,843 \\
\hline $1 \mathrm{H}-2^{*}$ & 25 & $1 / 12 / 2013$ & 1.525 & 1.525 & 34.16 & 420 & 0.76 & 2.23 & 26,857 & 7.39 & 21.62 & 4,261 \\
\hline
\end{tabular}

* = data used in the calculation of NMS values and in the splice. All data are included, however, in the event that the splice is modified and NMS values need to be recalculated. Only a portion of this table appears here. The complete table is available in ASCII and in Microsoft Excel format (see RAWXRF_U1335.XLS in RAWXRF in "Supplementary material.") 
Table T2. Raw X-ray fluorescence area data and calculated normalized median-squared (NMS) spliced data for all scans, Site U1336.

\begin{tabular}{|c|c|c|c|c|c|c|c|c|c|c|c|c|}
\hline $\begin{array}{l}\text { Core, } \\
\text { section }\end{array}$ & $\begin{array}{l}\text { Depth } \\
\text { in section } \\
(\mathrm{mm})\end{array}$ & $\begin{array}{l}\text { Measurement } \\
\text { date }\end{array}$ & $\begin{array}{l}\text { Depth (mbsf } \\
\text { [m revised } \\
\text { CSF-A] })\end{array}$ & $\begin{array}{l}\text { Depth (mcd } \\
\text { [m revised } \\
\text { CCSF-A]) }\end{array}$ & $\begin{array}{l}\text { Raw } \\
\text { component } \\
\text { sum } \\
(\%)\end{array}$ & $\begin{array}{c}\text { Al } \\
\text { area }\end{array}$ & $\begin{array}{c}\mathrm{Al} \\
\text { median- } \\
\text { scale }\end{array}$ & $\begin{array}{l}\mathrm{Al}_{2} \mathrm{O}_{3} \\
\mathrm{NMS}\end{array}$ & $\begin{array}{c}\mathrm{Si} \\
\text { area }\end{array}$ & $\begin{array}{c}\mathrm{Si} \\
\text { median- } \\
\text { scale }\end{array}$ & $\begin{array}{l}\mathrm{SiO}_{2} \\
\mathrm{NMS}\end{array}$ & $\begin{array}{c}\mathrm{S} \\
\text { area }\end{array}$ \\
\hline \multicolumn{13}{|c|}{ 320-U1336B- } \\
\hline $1 \mathrm{H}-1^{*}$ & 25 & $1 / 26 / 2012$ & 0.025 & 0.025 & 8.45 & 234 & 0.42 & 4.92 & 7,983 & 1.85 & 21.91 & 1,147 \\
\hline $1 \mathrm{H}-1^{*}$ & 50 & $1 / 26 / 2012$ & 0.05 & 0.05 & 21.98 & 515 & 0.91 & 4.16 & 17,624 & 4.09 & 18.59 & 1,727 \\
\hline $1 \mathrm{H}-1^{*}$ & 75 & $1 / 26 / 2012$ & 0.075 & 0.075 & 15.42 & 234 & 0.42 & 2.70 & 11,130 & 2.58 & 16.74 & 1,465 \\
\hline $1 \mathrm{H}-1^{*}$ & 100 & $1 / 26 / 2012$ & 0.1 & 0.1 & 16.38 & 326 & 0.58 & 3.54 & 12,401 & 2.87 & 17.56 & 1,625 \\
\hline $1 \mathrm{H}-1^{*}$ & 125 & $1 / 26 / 2012$ & 0.125 & 0.125 & 17.61 & 466 & 0.83 & 4.70 & 13,580 & 3.15 & 17.88 & 1,883 \\
\hline $1 \mathrm{H}-1^{*}$ & 150 & $1 / 26 / 2012$ & 0.15 & 0.15 & 18.61 & 624 & 1.11 & 5.96 & 16,311 & 3.78 & 20.32 & 2,408 \\
\hline $1 \mathrm{H}-1^{*}$ & 175 & $1 / 26 / 2012$ & 0.175 & 0.175 & 37.65 & 418 & 0.74 & 1.97 & 18,327 & 4.25 & 11.28 & 3,911 \\
\hline $1 \mathrm{H}-1^{*}$ & 200 & $1 / 26 / 2012$ & 0.2 & 0.2 & 40.61 & 291 & 0.52 & 1.27 & 20,255 & 4.70 & 11.56 & 4,031 \\
\hline $1 \mathrm{H}-1^{*}$ & 225 & $1 / 26 / 2012$ & 0.225 & 0.225 & 48.01 & 391 & 0.69 & 1.45 & 24,485 & 5.68 & 11.82 & 3,980 \\
\hline $1 \mathrm{H}-1^{*}$ & 250 & $1 / 26 / 2012$ & 0.25 & 0.25 & 53.40 & 419 & 0.74 & 1.39 & 23,143 & 5.37 & 10.05 & 4,435 \\
\hline $1 \mathrm{H}-1^{*}$ & 275 & $1 / 26 / 2012$ & 0.275 & 0.275 & 56.10 & 354 & 0.63 & 1.12 & 25,459 & 5.90 & 10.52 & 4,420 \\
\hline $1 \mathrm{H}-1^{*}$ & 300 & $1 / 26 / 2012$ & 0.3 & 0.3 & 62.71 & 257 & 0.46 & 0.73 & 22,320 & 5.17 & 8.25 & 3,174 \\
\hline $1 \mathrm{H}-1^{*}$ & 325 & $1 / 26 / 2012$ & 0.325 & 0.325 & 70.00 & 269 & 0.48 & 0.68 & 23,739 & 5.50 & 7.86 & 3,742 \\
\hline $1 \mathrm{H}-1^{*}$ & 350 & $1 / 26 / 2012$ & 0.35 & 0.35 & 70.40 & 307 & 0.55 & 0.77 & 22,399 & 5.19 & 7.38 & 4,117 \\
\hline $1 \mathrm{H}-1^{*}$ & 375 & $1 / 26 / 2012$ & 0.375 & 0.375 & 53.81 & 237 & 0.42 & 0.78 & 21,863 & 5.07 & 9.42 & 3,684 \\
\hline $1 \mathrm{H}-1^{*}$ & 425 & $1 / 26 / 2012$ & 0.425 & 0.425 & 51.82 & 307 & 0.55 & 1.05 & 22,083 & 5.12 & 9.88 & 3,220 \\
\hline $1 \mathrm{H}-1^{*}$ & 450 & $1 / 26 / 2012$ & 0.45 & 0.45 & 56.23 & 423 & 0.75 & 1.34 & 27,602 & 6.40 & 11.38 & 4,298 \\
\hline $1 \mathrm{H}-1^{*}$ & 475 & $1 / 26 / 2012$ & 0.475 & 0.475 & 58.35 & 602 & 1.07 & 1.83 & 30,017 & 6.96 & 11.93 & 4,250 \\
\hline $1 \mathrm{H}-1^{*}$ & 500 & $1 / 26 / 2012$ & 0.5 & 0.5 & 55.43 & 722 & 1.28 & 2.31 & 28,419 & 6.59 & 11.89 & 3,883 \\
\hline $1 \mathrm{H}-1^{*}$ & 525 & $1 / 26 / 2012$ & 0.525 & 0.525 & 55.74 & 425 & 0.75 & 1.35 & 24,976 & 5.79 & 10.39 & 4,104 \\
\hline $1 \mathrm{H}-1^{*}$ & 550 & $1 / 26 / 2012$ & 0.55 & 0.55 & 59.88 & 630 & 1.12 & 1.87 & 26,767 & 6.21 & 10.36 & 4,048 \\
\hline $1 \mathrm{H}-1$ & 575 & $1 / 26 / 2012$ & 0.575 & 0.575 & 66.43 & 484 & 0.86 & 1.29 & 28,077 & 6.51 & 9.80 & 3,236 \\
\hline $1 \mathrm{H}-1$ & 600 & $1 / 26 / 2012$ & 0.6 & 0.6 & 71.70 & 524 & 0.93 & 1.30 & 26,864 & 6.23 & 8.69 & 2,843 \\
\hline $1 \mathrm{H}-1$ & 625 & $1 / 26 / 2012$ & 0.625 & 0.625 & 79.08 & 574 & 1.02 & 1.29 & 26,452 & 6.13 & 7.75 & 3,042 \\
\hline $1 \mathrm{H}-1$ & 650 & $1 / 26 / 2012$ & 0.65 & 0.65 & 78.47 & 417 & 0.74 & 0.94 & 26,176 & 6.07 & 7.73 & 2,396 \\
\hline $1 \mathrm{H}-1$ & 675 & $1 / 26 / 2012$ & 0.675 & 0.675 & 83.66 & 517 & 0.92 & 1.10 & 31,131 & 7.22 & 8.63 & 2,580 \\
\hline $1 \mathrm{H}-1$ & 700 & $1 / 26 / 2012$ & 0.7 & 0.7 & 79.89 & 207 & 0.37 & 0.46 & 27,936 & 6.48 & 8.11 & 2,591 \\
\hline $1 \mathrm{H}-1$ & 725 & $1 / 26 / 2012$ & 0.725 & 0.725 & 83.14 & 604 & 1.07 & 1.29 & 29,651 & 6.87 & 8.27 & 3,144 \\
\hline $1 \mathrm{H}-1$ & 750 & $1 / 26 / 2012$ & 0.75 & 0.75 & 76.09 & 357 & 0.63 & 0.83 & 27,497 & 6.37 & 8.38 & 2,443 \\
\hline $1 \mathrm{H}-1$ & 775 & $1 / 26 / 2012$ & 0.775 & 0.775 & 75.66 & 401 & 0.71 & 0.94 & 27,357 & 6.34 & 8.38 & 3,028 \\
\hline $1 \mathrm{H}-1$ & 800 & $1 / 26 / 2012$ & 0.8 & 0.8 & 82.64 & 497 & 0.88 & 1.07 & 29,564 & 6.85 & 8.29 & 2,443 \\
\hline $1 \mathrm{H}-1$ & 825 & $1 / 26 / 2012$ & 0.825 & 0.825 & 79.41 & 593 & 1.05 & 1.33 & 29,282 & 6.79 & 8.55 & 1,864 \\
\hline $1 \mathrm{H}-1$ & 850 & $1 / 26 / 2012$ & 0.85 & 0.85 & 79.31 & 139 & 0.25 & 0.31 & 29,000 & 6.72 & 8.48 & 2,374 \\
\hline $1 \mathrm{H}-1$ & 875 & $1 / 26 / 2012$ & 0.875 & 0.875 & 74.25 & 519 & 0.92 & 1.24 & 26,703 & 6.19 & 8.34 & 2,425 \\
\hline $1 \mathrm{H}-1$ & 900 & $1 / 26 / 2012$ & 0.9 & 0.9 & 78.46 & 194 & 0.34 & 0.44 & 28,127 & 6.52 & 8.31 & 2,221 \\
\hline $1 \mathrm{H}-1$ & 925 & $1 / 26 / 2012$ & 0.925 & 0.925 & 77.92 & 371 & 0.66 & 0.85 & 29,093 & 6.74 & 8.66 & 2,737 \\
\hline $1 \mathrm{H}-1$ & 950 & $1 / 26 / 2012$ & 0.95 & 0.95 & 79.51 & 459 & 0.82 & 1.03 & 28,987 & 6.72 & 8.45 & 2,554 \\
\hline $1 \mathrm{H}-1$ & 975 & $1 / 26 / 2012$ & 0.975 & 0.975 & 73.47 & 617 & 1.10 & 1.49 & 27,214 & 6.31 & 8.59 & 2,630 \\
\hline $1 \mathrm{H}-1$ & 1,000 & $1 / 26 / 2012$ & 1 & 1 & 68.47 & 416 & 0.74 & 1.08 & 26,121 & 6.06 & 8.84 & 1,857 \\
\hline $1 \mathrm{H}-1$ & 1,025 & $1 / 26 / 2012$ & 1.025 & 1.025 & 65.80 & 416 & 0.74 & 1.12 & 24,245 & 5.62 & 8.54 & 1,924 \\
\hline $1 \mathrm{H}-1$ & 1,050 & $1 / 26 / 2012$ & 1.05 & 1.05 & 65.73 & 614 & 1.09 & 1.66 & 27,143 & 6.29 & 9.57 & 2,327 \\
\hline $1 \mathrm{H}-1$ & 1,075 & $1 / 26 / 2012$ & 1.075 & 1.075 & 66.25 & 352 & 0.63 & 0.94 & 26,188 & 6.07 & 9.16 & 2,118 \\
\hline $1 \mathrm{H}-1$ & 1,100 & $1 / 26 / 2012$ & 1.1 & 1.1 & 57.94 & 515 & 0.91 & 1.58 & 23,234 & 5.39 & 9.30 & 1,719 \\
\hline $1 \mathrm{H}-1$ & 1,125 & $1 / 26 / 2012$ & 1.125 & 1.125 & 59.47 & 487 & 0.86 & 1.45 & 21,585 & 5.00 & 8.41 & 1,682 \\
\hline $1 \mathrm{H}-1$ & 1,150 & $1 / 26 / 2012$ & 1.15 & 1.15 & 63.63 & 600 & 1.07 & 1.67 & 26,999 & 6.26 & 9.84 & 2,831 \\
\hline $1 \mathrm{H}-1$ & 1,175 & $1 / 26 / 2012$ & 1.175 & 1.175 & 59.26 & 546 & 0.97 & 1.64 & 26,543 & 6.15 & 10.38 & 1,893 \\
\hline $1 \mathrm{H}-1$ & 1,200 & $1 / 26 / 2012$ & 1.2 & 1.2 & 57.27 & 709 & 1.26 & 2.20 & 29,222 & 6.77 & 11.83 & 1,896 \\
\hline $1 \mathrm{H}-1$ & 1,225 & $1 / 26 / 2012$ & 1.225 & 1.225 & 46.44 & 522 & 0.93 & 2.00 & 24,978 & 5.79 & 12.47 & 1,721 \\
\hline $1 \mathrm{H}-1$ & 1,275 & $1 / 26 / 2012$ & 1.275 & 1.275 & 54.01 & 819 & 1.45 & 2.69 & 28,804 & 6.68 & 12.36 & 1,988 \\
\hline $1 \mathrm{H}-1$ & 1,300 & $1 / 26 / 2012$ & 1.3 & 1.3 & 63.90 & 396 & 0.70 & 1.10 & 30,668 & 7.11 & 11.13 & 2,211 \\
\hline $1 \mathrm{H}-1$ & 1,325 & $1 / 26 / 2012$ & 1.325 & 1.325 & 69.75 & 852 & 1.51 & 2.17 & 31,757 & 7.36 & 10.55 & 3,130 \\
\hline $1 \mathrm{H}-1$ & 1,350 & $1 / 26 / 2012$ & 1.35 & 1.35 & 61.91 & 665 & 1.18 & 1.91 & 28,453 & 6.60 & 10.65 & 2,541 \\
\hline $1 \mathrm{H}-1$ & 1,375 & $1 / 26 / 2012$ & 1.375 & 1.375 & 69.44 & 524 & 0.93 & 1.34 & 25,995 & 6.03 & 8.68 & 2,579 \\
\hline \multicolumn{13}{|c|}{ 320/321-U1336A- } \\
\hline $1 \mathrm{H}-1$ & 25 & $1 / 24 / 2012$ & 0.025 & 0.285 & 19.16 & 413 & 0.73 & 3.83 & 16,539 & 3.83 & 20.01 & 1,842 \\
\hline $1 \mathrm{H}-1$ & 50 & $1 / 24 / 2012$ & 0.05 & 0.31 & 38.92 & 979 & 1.74 & 4.47 & 27,221 & 6.31 & 16.22 & 2,812 \\
\hline $1 \mathrm{H}-1$ & 75 & $1 / 24 / 2012$ & 0.075 & 0.335 & 26.51 & 732 & 1.30 & 4.90 & 21,279 & 4.93 & 18.61 & 2,396 \\
\hline $1 \mathrm{H}-1$ & 100 & $1 / 24 / 2012$ & 0.1 & 0.36 & 27.86 & 1072 & 1.90 & 6.83 & 24,538 & 5.69 & 20.42 & 2,349 \\
\hline $1 \mathrm{H}-1$ & 125 & $1 / 24 / 2012$ & 0.125 & 0.385 & 27.46 & 662 & 1.18 & 4.28 & 22,855 & 5.30 & 19.29 & 2,911 \\
\hline
\end{tabular}

* = data used in the calculation of NMS values and in the splice. All data are included, however, in the event that the splice is modified and NMS values need to be recalculated. Only a portion of this table appears here. The complete table is available in ASCII and in Microsoft Excel format (see RAWXRF_U1336.XLS in RAWXRF in "Supplementary material.") 
Table T3. Raw X-ray fluorescence area data and calculated normalized median-squared (NMS) spliced data for all scans, Site U1337.

\begin{tabular}{|c|c|c|c|c|c|c|c|c|c|c|c|c|}
\hline $\begin{array}{l}\text { Core, } \\
\text { section }\end{array}$ & $\begin{array}{l}\text { Depth } \\
\text { in section } \\
(\mathrm{mm})\end{array}$ & $\begin{array}{l}\text { Measurement } \\
\text { date }\end{array}$ & $\begin{array}{l}\text { Depth (mbsf } \\
\text { [m revised } \\
\text { CSF-A]) }\end{array}$ & $\begin{array}{l}\text { Depth (mcd } \\
\text { [m revised } \\
\text { CCSF-A]) }\end{array}$ & $\begin{array}{l}\text { Raw } \\
\text { component } \\
\text { sum } \\
(\%)\end{array}$ & $\begin{array}{c}\mathrm{Al} \\
\text { area }\end{array}$ & $\begin{array}{l}\text { Al } \\
\text { median- } \\
\text { scale }\end{array}$ & $\begin{array}{l}\mathrm{Al}_{2} \mathrm{O}_{3} \\
\mathrm{NMS}\end{array}$ & $\begin{array}{c}\mathrm{Si} \\
\text { area }\end{array}$ & $\begin{array}{c}\mathrm{Si} \\
\text { median- } \\
\text { scale }\end{array}$ & $\begin{array}{l}\mathrm{SiO}_{2} \\
\mathrm{NMS}\end{array}$ & $\begin{array}{c}\mathrm{S} \\
\text { area }\end{array}$ \\
\hline \multicolumn{13}{|c|}{ 321-U1337B- } \\
\hline $1 \mathrm{H}-1^{*}$ & 25 & $9 / 20 / 2012$ & 1.025 & 0.025 & 51.55 & 280 & 0.71 & 1.37 & 28,368 & 15.11 & 29.32 & 6,694 \\
\hline $1 \mathrm{H}-1^{*}$ & 50 & $9 / 20 / 2012$ & 1.05 & 0.05 & 55.11 & -59 & 0.00 & 0.00 & 25,856 & 13.77 & 24.99 & 9,528 \\
\hline $1 \mathrm{H}-1^{*}$ & 75 & $9 / 20 / 2012$ & 1.075 & 0.075 & 81.76 & 229 & 0.58 & 0.71 & 38,038 & 20.26 & 24.78 & 8,085 \\
\hline $1 \mathrm{H}-1^{*}$ & 100 & 9/20/2012 & 1.1 & 0.1 & 70.87 & 404 & 1.02 & 1.44 & 41,109 & 21.90 & 30.90 & 9,550 \\
\hline $1 \mathrm{H}-1^{*}$ & 125 & 9/20/2012 & 1.125 & 0.125 & 82.37 & -146 & 0.00 & 0.00 & 35,381 & 18.85 & 22.88 & 7,217 \\
\hline $1 \mathrm{H}-1^{*}$ & 150 & 9/20/2012 & 1.15 & 0.15 & 107.58 & 242 & 0.61 & 0.57 & 41,586 & 22.15 & 20.59 & 5,909 \\
\hline $1 \mathrm{H}-1^{*}$ & 175 & $9 / 20 / 2012$ & 1.175 & 0.175 & 106.35 & 101 & 0.26 & 0.24 & 43,714 & 23.29 & 21.90 & 6,345 \\
\hline $1 \mathrm{H}-1^{*}$ & 200 & $9 / 20 / 2012$ & 1.2 & 0.2 & 94.20 & 222 & 0.56 & 0.60 & 40,227 & 21.43 & 22.75 & 6,746 \\
\hline $1 \mathrm{H}-1^{*}$ & 225 & 9/20/2012 & 1.225 & 0.225 & 99.85 & 18 & 0.05 & 0.05 & 37,076 & 19.75 & 19.78 & 6,266 \\
\hline $1 \mathrm{H}-1^{*}$ & 250 & 9/20/2012 & 1.25 & 0.25 & 99.47 & 118 & 0.30 & 0.30 & 35,159 & 18.73 & 18.83 & 6,167 \\
\hline $1 \mathrm{H}-1^{*}$ & 275 & 9/20/2012 & 1.275 & 0.275 & 96.11 & 105 & 0.27 & 0.28 & 34,701 & 18.49 & 19.23 & 6,831 \\
\hline $1 \mathrm{H}-1^{*}$ & 300 & 9/20/2012 & 1.3 & 0.3 & 95.69 & -166 & 0.00 & 0.00 & 34,425 & 18.34 & 19.16 & 6,130 \\
\hline $1 \mathrm{H}-1^{*}$ & 325 & $9 / 20 / 2012$ & 1.325 & 0.325 & 92.35 & -61 & 0.00 & 0.00 & 31,968 & 17.03 & 18.44 & 6,566 \\
\hline $1 \mathrm{H}-1^{*}$ & 350 & 9/20/2012 & 1.35 & 0.35 & 100.10 & -137 & 0.00 & 0.00 & 31,104 & 16.57 & 16.55 & 6,879 \\
\hline $1 \mathrm{H}-1$ * & 375 & 9/20/2012 & 1.375 & 0.375 & 103.30 & -89 & 0.00 & 0.00 & 33,026 & 17.59 & 17.03 & 6,634 \\
\hline $1 \mathrm{H}-1^{*}$ & 400 & 9/20/2012 & 1.4 & 0.4 & 101.32 & -66 & 0.00 & 0.00 & 31,896 & 16.99 & 16.77 & 5,777 \\
\hline $1 \mathrm{H}-1^{*}$ & 425 & $9 / 20 / 2012$ & 1.425 & 0.425 & 104.41 & 31 & 0.08 & 0.08 & 30,084 & 16.03 & 15.35 & 5,463 \\
\hline $1 \mathrm{H}-1^{*}$ & 450 & $9 / 20 / 2012$ & 1.45 & 0.45 & 104.42 & -24 & 0.00 & 0.00 & 23,121 & 12.32 & 11.80 & 5,300 \\
\hline $1 \mathrm{H}-1^{*}$ & 475 & $9 / 20 / 2012$ & 1.475 & 0.475 & 104.45 & -41 & 0.00 & 0.00 & 24,051 & 12.81 & 12.27 & 5,218 \\
\hline $1 \mathrm{H}-1^{*}$ & 500 & $9 / 20 / 2012$ & 1.5 & 0.5 & 99.86 & -69 & 0.00 & 0.00 & 23,024 & 12.27 & 12.28 & 5,762 \\
\hline $1 \mathrm{H}-1^{*}$ & 525 & 9/20/2012 & 1.525 & 0.525 & 93.20 & 140 & 0.35 & 0.38 & 20,591 & 10.97 & 11.77 & 6,168 \\
\hline $1 \mathrm{H}-1^{*}$ & 550 & 9/20/2012 & 1.55 & 0.55 & 86.75 & -98 & 0.00 & 0.00 & 20,189 & 10.75 & 12.40 & 6,963 \\
\hline $1 \mathrm{H}-1^{*}$ & 575 & $9 / 20 / 2012$ & 1.575 & 0.575 & 101.25 & -117 & 0.00 & 0.00 & 28,243 & 15.05 & 14.86 & 5,823 \\
\hline $1 \mathrm{H}-1^{*}$ & 600 & 9/20/2012 & 1.6 & 0.6 & 85.96 & -2 & 0.00 & 0.00 & 21,225 & 11.31 & 13.15 & 6,784 \\
\hline $1 \mathrm{H}-1^{*}$ & 625 & 9/20/2012 & 1.625 & 0.625 & 96.94 & 137 & 0.35 & 0.36 & 27,568 & 14.69 & 15.15 & 6,344 \\
\hline $1 \mathrm{H}-1^{*}$ & 650 & 9/20/2012 & 1.65 & 0.65 & 96.30 & 13 & 0.03 & 0.03 & 26,857 & 14.31 & 14.86 & 6,873 \\
\hline $1 \mathrm{H}-1^{*}$ & 675 & 9/20/2012 & 1.675 & 0.675 & 96.39 & -101 & 0.00 & 0.00 & 25,476 & 13.57 & 14.08 & 6,091 \\
\hline $1 \mathrm{H}-1^{*}$ & 700 & $9 / 20 / 2012$ & 1.7 & 0.7 & 97.56 & -98 & 0.00 & 0.00 & 23,686 & 12.62 & 12.93 & 6,394 \\
\hline $1 \mathrm{H}-1^{*}$ & 725 & $9 / 20 / 2012$ & 1.725 & 0.725 & 95.54 & -89 & 0.00 & 0.00 & 28,644 & 15.26 & 15.97 & 6,482 \\
\hline $1 \mathrm{H}-1^{*}$ & 750 & 9/20/2012 & 1.75 & 0.75 & 91.02 & 175 & 0.44 & 0.49 & 26,896 & 14.33 & 15.74 & 6,646 \\
\hline $1 \mathrm{H}-1^{*}$ & 775 & 9/20/2012 & 1.775 & 0.775 & 86.75 & -87 & 0.00 & 0.00 & 22,932 & 12.22 & 14.08 & 7,080 \\
\hline $1 \mathrm{H}-1^{*}$ & 800 & 9/20/2012 & 1.8 & 0.8 & 86.81 & 70 & 0.18 & 0.20 & 25,358 & 13.51 & 15.56 & 7,735 \\
\hline $1 \mathrm{H}-1^{*}$ & 825 & $9 / 20 / 2012$ & 1.825 & 0.825 & 79.65 & -117 & 0.00 & 0.00 & 26,569 & 14.15 & 17.77 & 7,749 \\
\hline $1 \mathrm{H}-1^{*}$ & 850 & $9 / 20 / 2012$ & 1.85 & 0.85 & 73.55 & -44 & 0.00 & 0.00 & 25,291 & 13.47 & 18.32 & 7,516 \\
\hline $1 \mathrm{H}-1^{*}$ & 875 & 9/20/2012 & 1.875 & 0.875 & 69.44 & 150 & 0.38 & 0.55 & 29,200 & 15.56 & 22.40 & 8,923 \\
\hline $1 \mathrm{H}-1$ * & 900 & 9/20/2012 & 1.9 & 0.9 & 65.49 & 39 & 0.10 & 0.15 & 30,413 & 16.20 & 24.74 & 9,562 \\
\hline $1 \mathrm{H}-1^{*}$ & 925 & 9/20/2012 & 1.925 & 0.925 & 41.92 & 38 & 0.10 & 0.23 & 25,171 & 13.41 & 31.99 & 11,508 \\
\hline $1 \mathrm{H}-1^{*}$ & 950 & $9 / 20 / 2012$ & 1.95 & 0.95 & 49.47 & -133 & 0.00 & 0.00 & 22,817 & 12.15 & 24.57 & 9,812 \\
\hline $1 \mathrm{H}-1^{*}$ & 975 & $9 / 20 / 2012$ & 1.975 & 0.975 & 41.60 & 229 & 0.58 & 1.39 & 24,555 & 13.08 & 31.44 & 11,090 \\
\hline $1 \mathrm{H}-1^{*}$ & 1,000 & 9/20/2012 & 2 & 1 & 30.32 & 181 & 0.46 & 1.51 & 19,513 & 10.39 & 34.28 & 11,206 \\
\hline $1 \mathrm{H}-1^{*}$ & 1,025 & 9/20/2012 & 2.025 & 1.025 & 41.34 & 465 & 1.17 & 2.84 & 31,520 & 16.79 & 40.62 & 11,684 \\
\hline $1 \mathrm{H}-1^{*}$ & 1,050 & $9 / 20 / 2012$ & 2.05 & 1.05 & 39.39 & 326 & 0.82 & 2.09 & 29,932 & 15.95 & 40.48 & 11,831 \\
\hline $1 \mathrm{H}-1^{*}$ & 1,075 & $9 / 20 / 2012$ & 2.075 & 1.075 & 45.77 & 571 & 1.44 & 3.15 & 40,392 & 21.52 & 47.01 & 11,794 \\
\hline $1 \mathrm{H}-1$ * & 1,100 & 9/20/2012 & 2.1 & 1.1 & 44.46 & 444 & 1.12 & 2.52 & 39,131 & 20.85 & 46.89 & 11,577 \\
\hline $1 \mathrm{H}-1^{*}$ & 1,125 & 9/20/2012 & 2.125 & 1.125 & 49.95 & 724 & 1.83 & 3.66 & 46,179 & 24.60 & 49.25 & 10,942 \\
\hline $1 \mathrm{H}-1^{*}$ & 1,150 & $9 / 20 / 2012$ & 2.15 & 1.15 & 54.37 & 1017 & 2.57 & 4.73 & 46,988 & 25.03 & 46.04 & 11,628 \\
\hline $1 \mathrm{H}-1^{*}$ & 1,175 & 9/20/2012 & 2.175 & 1.175 & 50.80 & 541 & 1.37 & 2.69 & 41,583 & 22.15 & 43.61 & 11,323 \\
\hline $1 \mathrm{H}-1^{*}$ & 1,200 & 9/20/2012 & 2.2 & 1.2 & 52.62 & 687 & 1.74 & 3.30 & 41,239 & 21.97 & 41.75 & 11,002 \\
\hline $1 \mathrm{H}-1^{*}$ & 1,225 & 9/20/2012 & 2.225 & 1.225 & 49.92 & 708 & 1.79 & 3.58 & 37,458 & 19.95 & 39.97 & 11,221 \\
\hline $1 \mathrm{H}-1^{*}$ & 1,250 & 9/20/2012 & 2.25 & 1.25 & 42.20 & 452 & 1.14 & 2.71 & 31,993 & 17.04 & 40.38 & 11,216 \\
\hline $1 \mathrm{H}-1^{*}$ & 1,275 & $9 / 20 / 2012$ & 2.275 & 1.275 & 47.69 & 609 & 1.54 & 3.23 & 31,515 & 16.79 & 35.20 & 11,249 \\
\hline $1 \mathrm{H}-1^{*}$ & 1,300 & 9/20/2012 & 2.3 & 1.3 & 48.88 & 163 & 0.41 & 0.84 & 33,025 & 17.59 & 35.99 & 10,357 \\
\hline $1 \mathrm{H}-1^{*}$ & 1,325 & 9/20/2012 & 2.325 & 1.325 & 39.16 & 456 & 1.15 & 2.94 & 30,855 & 16.44 & 41.98 & 11,512 \\
\hline $1 \mathrm{H}-1^{*}$ & 1,350 & 9/20/2012 & 2.35 & 1.35 & 45.04 & 203 & 0.51 & 1.14 & 26,385 & 14.06 & 31.20 & 10,343 \\
\hline $1 \mathrm{H}-1^{*}$ & 1,375 & $9 / 20 / 2012$ & 2.375 & 1.375 & 35.13 & -16 & 0.00 & 0.00 & 21,459 & 11.43 & 32.54 & 11,246 \\
\hline $1 \mathrm{H}-1^{*}$ & 1,400 & $9 / 20 / 2012$ & 2.4 & 1.4 & 35.84 & 346 & 0.87 & 2.44 & 31,992 & 17.04 & 47.56 & 10,927 \\
\hline $1 \mathrm{H}-1^{*}$ & 1,425 & 9/20/2012 & 2.425 & 1.425 & 31.88 & 543 & 1.37 & 4.30 & 28,565 & 15.22 & 47.74 & 11,238 \\
\hline $1 \mathrm{H}-1^{*}$ & 1,450 & $9 / 20 / 2012$ & 2.45 & 1.45 & 38.55 & 550 & 1.39 & 3.60 & 27,729 & 14.77 & 38.32 & 10,873 \\
\hline $1 \mathrm{H}-2^{*}$ & 25 & 9/20/2012 & 2.525 & 1.525 & 45.68 & 858 & 2.17 & 4.75 & 47,690 & 25.40 & 55.62 & 10,161 \\
\hline
\end{tabular}

* = data used in the calculation of NMS values and in the splice. All data are included, however, in the event that the splice is modified and NMS values need to be recalculated. Only a portion of this table appears here. The complete table is available in ASCII and in Microsoft Excel format (see RAWXRF_U1337.XLS in RAWXRF in "Supplementary material.") 
Table T4. Shipboard weight percent and calculated area medians for sedimentary components at each site used in calculating final normalized median-squared values, Sites U1335-U1337.

\begin{tabular}{|c|c|c|c|c|c|c|}
\hline \multirow[b]{2}{*}{ Component } & \multicolumn{2}{|c|}{ Site U1335 } & \multicolumn{2}{|c|}{ Site U1336 } & \multicolumn{2}{|c|}{ Site U1337 } \\
\hline & $\begin{array}{c}\text { Shipboard } \\
\text { (wt\%) }\end{array}$ & $\begin{array}{c}\text { Calculated } \\
\text { area }\end{array}$ & $\begin{array}{c}\text { Shipboard } \\
\text { (wt\%) }\end{array}$ & $\begin{array}{c}\text { Calculated } \\
\text { area }\end{array}$ & $\begin{array}{l}\text { Shipboard } \\
\text { (wt\%) }\end{array}$ & $\begin{array}{c}\text { Calculated } \\
\text { area }\end{array}$ \\
\hline $\mathrm{Al}_{2} \mathrm{O}_{3}$ & 0.420 & 232 & 0.222 & 125 & 0.720 & 285 \\
\hline $\mathrm{SiO}_{2}$ & 9.030 & $32,831.5$ & 4.570 & 19,713 & 25.085 & $47,089.5$ \\
\hline $\mathrm{K}_{2} \mathrm{O}$ & 0.110 & 3,296 & 0.046 & 2,105 & 0.198 & 5,350 \\
\hline $\mathrm{CaCO}_{3}$ & 72.277 & $2,504,943$ & 87.625 & $2,497,635$ & 70.136 & $1,996,713$ \\
\hline $\mathrm{TiO}_{2}$ & 0.070 & 2,020 & 0.019 & 1,296 & 0.143 & 1,691 \\
\hline $\mathrm{MnO}$ & 0.050 & $3,366.5$ & 0.089 & 4,740 & 0.181 & $9,542.5$ \\
\hline $\mathrm{Fe}_{2} \mathrm{O}_{3}$ & 0.470 & 29,862 & 0.427 & 35,612 & 0.730 & 43,429 \\
\hline $\mathrm{BaSO}_{4}$ & 0.301 & 5,551 & 0.235 & 3,139 & 0.549 & 7,507 \\
\hline
\end{tabular}

Medians of shipboard data were for all points measured at each site.

Table T5. Age, depth, and stratigraphic data, Sites U1335-U1337.

\begin{tabular}{|c|c|c|c|c|}
\hline Datum & $\begin{array}{l}\text { Age } \\
\text { (Ma) }\end{array}$ & $\begin{array}{l}\text { Site U1335 } \\
\text { depth } \\
\text { (mcd) }\end{array}$ & $\begin{array}{l}\text { Site U1336 } \\
\text { depth } \\
\text { (mcd) }\end{array}$ & $\begin{array}{l}\text { Site U1337 } \\
\text { depth } \\
\text { (mcd) }\end{array}$ \\
\hline T Pseudoemiliania lacunosa & 0.44 & 2.34 & & 5.84 \\
\hline $\mathrm{C} 1 \mathrm{r} .2 \mathrm{r}-\mathrm{C} 2 \mathrm{n}$ & 1.778 & 10.545 & & 27.23 \\
\hline C2An.2n-C2An.2r & 3.207 & 17.735 & & 47.98 \\
\hline$C 3 n .1 r-C 3 n .2 n$ & 4.493 & 23.885 & & 78.31 \\
\hline $\mathrm{C} 3 n .4 n-C 3 r$ & 5.235 & 29.82 & & 94.47 \\
\hline C3An.2n-C3Ar & 6.733 & 40.03 & & 129.805 \\
\hline T Discoaster hamatus & 9.69 & 66.115 & & 192.985 \\
\hline T Coronocyclus nitescens & 12.12 & 94.95 & 1.36 & 258.305 \\
\hline C5ADn-C5ADr & 14.581 & 156.675 & 30.205 & \\
\hline Tc Discoaster deflandrei & 15.66 & 180.6 & 33.705 & 357.87 \\
\hline C5Cn.1r-C5Cn.2n & 16.256 & 191.06 & 46.13 & \\
\hline Bc Sphenolithus heteromorphus & 17.71 & 206.33 & & 390.5 \\
\hline B Sphenolithus belemnos & 19.03 & 236.92 & 84.135 & 412.32 \\
\hline
\end{tabular}

Both biostratigraphic and magnetostratigraphic points were used. $\mathrm{T}=$ top, $\mathrm{Tc}=$ top common, $\mathrm{BC}=$ bottom common, $\mathrm{B}=$ bottom. 